\title{
Chapter 13 \\ The Reptiles of Angola: History, Diversity, Endemism and Hotspots
}

\author{
William R. Branch, Pedro Vaz Pinto, Ninda Baptista, and Werner Conradie
}

\begin{abstract}
This review summarises the current status of our knowledge of Angolan reptile diversity, and places it into a historical context of understanding and growth. It is compared and contrasted with known diversity in adjacent regions to allow insight into taxonomic status and biogeographic patterns. Over 67\% of Angolan reptiles were described by the end of the nineteenth century. Studies stagnated during the twentieth century but have increased in the last decade. At least 278 reptiles are currently known, but numerous new discoveries have been made during recent surveys, and many novelties await description. Although lizard and snake diversity is currently almost equal, most new discoveries occur in lizards, particularly geckos and lacertids. Poorly known Angolan reptiles and others from adjacent regions that
\end{abstract}

\footnotetext{
W. R. Branch (deceased)

National Geographic Okavango Wilderness Project, Wild Bird Trust, Hogsback, South Africa

Department of Zoology, Nelson Mandela University, Port Elizabeth, South Africa

P. Vaz Pinto

Fundação Kissama, Luanda, Angola

CIBIO-InBIO, Centro de Investigação em Biodiversidade e Recursos Genéticos, Universidade do Porto, Campus de Vairão, Vairão, Portugal

e-mail: pedrovazpinto@gmail.com

N. Baptista

National Geographic Okavango Wilderness Project, Wild Bird Trust, Hogsback, South Africa CIBIO-InBIO, Centro de Investigação em Biodiversidade e Recursos Genéticos, Universidade do Porto, Campus de Vairão, Vairão, Portugal

Instituto Superior de Ciências da Educação da Huíla, Rua Sarmento Rodrigues, Lubango, Angola

e-mail: nindabaptista@gmail.com

W. Conradie $(\square)$

National Geographic Okavango Wilderness Project, Wild Bird Trust, Hogsback, South Africa School of Natural Resource Management, Nelson Mandela University, George, South Africa Port Elizabeth Museum (Bayworld), Humewood, South Africa e-mail: werner@bayworld.co.za
} 
may occur in the country are highlighted. Most endemic Angolan reptiles are lizards and are associated with the escarpment and southwest arid region. Identification of reptile diversity hotspots are resolving but require targeted surveys for their delimitation and to enable protection. These include the Kaokoveld Centre of Endemism, Angolan Escarpment and the Congo forests of the north. The fauna of Angola remains poorly known and under-appreciated, but it is already evident that it forms an important centre of African reptile diversity and endemism.

Keywords Herpetofauna $\cdot$ History $\cdot$ Priority studies $\cdot$ Reptilia $\cdot$ Review

\section{Introduction}

Systematic biology is the backbone of biology in that it describes the taxa and their relationships which then serve as the objects of research. (Uetz and Stylianou 2018)

The extensive territory of Angola is for herpetologists one of the least known parts of Africa. This is particularly unfortunate because there are indications that it may be one of the most interesting areas of the continent. (Gans 1976)

The need to classify things is a basic human need. Initially it was simply utilitarian, driven by the necessity for rural people to know what was edible, venomous, poisonous, or useful. As the world's diverse civilizations developed all were faced with the need to refine this knowledge, and as they migrated, came together, experienced new habitats and new life forms, the need for classification became essential. Only when new technological innovations in such things as sailing and weaponry allowed the reach of various nations to become global, did universal categorisation and classification really need to be become standardised. Driven by the Enlightenment and during the rise of critical thinking and the scientific revolution there began the first steps in developing a universally recognised system for classifying Life. The current classification system was initiated by Carl Linnaeus (1707-1778), a Swedish botanist, physician, and zoologist who formalised the modern system of naming organisms, now known as binomial nomenclature. During the $250+$ years since the Linnaean revolution, the rules used to name this diversity have been refined and modified, and increasingly sophisticated methods have been developed to gain insight into the relationships of its components.

Since the equally important Darwinian Revolution and awareness of the evolutionary relatedness of Life, modern systematics places emphasis on revealing patterns of relationship among groups, often figuratively represented as trees or cladograms. The branches of these 'trees' are monophyletic when they include only the descendants of a common ancestor. All modern classifications comprise hypotheses represented as phylogenies of nested groups (clades) exhibiting monophyly. Biochemical adjuncts to traditional taxonomy have proliferated since the middle of the last century, but detailed multi-taxon genomic analysis, linked with increasingly sophisticated computer processing of sequence data, is a phenomenon of the twenty-first century. These recent technological advances have allowed objective assessments of hypotheses of phylogenetic relationships. It is important to emphasise that the assignment of any individual 
specimen, first to a species and then to any higher taxonomic group, tests hypotheses of relationships. The placement of a specimen at any level in the nomenclatural hierarchy, from species to phylum, must conform to the definitions of those groups. It should be stressed, moreover, that taxonomy is a dynamic discipline and that every assignment of a specimen to a species or higher taxonomic group is a hypothesis of relationship. It is always subject to revision in the light of new knowledge.

It has become increasingly obvious that species may result from different mechanisms and histories, and there is increasing use of evolutionary and phylogenetic species concepts to reflect hypotheses about the boundaries of past and present gene transfer within evolutionary lineages of Life's diversity. Many phylogenies based on molecular/genetic data conflict with historical ideas of relationships previously based solely or largely on morphological analysis. It is evident that morphology is often conservative (maintained by selective pressures) that may mask underlying cryptic genetic diversity. This awareness has led to the burgeoning description of new species, genera, and higher categories.

\section{History: Early Research on Angolan Reptiles}

Early studies on the Angolan herpetofauna have been summarised by Baptista et al. (2019) in this volume, also see the recently published Angola Reptile and Amphibian Atlas (Marques et al. 2018). Other recent summaries can be found in introductions to regional herpetofaunas, e.g. Ceríaco et al. (2014a, 2016a) and Conradie et al. (2016). To avoid duplication much will not be repeated here, where instead emphasis is placed on the main publications discussing Angolan reptiles during and after the colonial period, and particularly the periodic attempts to overview its diversity (Bocage 1895; Monard 1937).

José Vincente Barbosa du Bocage is rightly known as the 'Father of Angolan Herpetology'. He was, however, more than just a scientist and for much of his life held multiple positions in government, administration and science, often simultaneously. De Almeida (2011) reviews diverse aspects of his multifaceted life; Madruga (2013) discusses the development of his scientific career; and Gamito-Marques (2017) explains Bocage's role in the foundation of National Museum of Lisbon and his importance, via his contacts with collectors in various Portuguese colonies as well as other zoologists at major European museums, in developing the collections and status of the museum. A list of his scientific publications is available at TRIPLOV (2018). In his first attempt to review the known Angolan herpetofauna he listed 26 reptile species from the Congo and 57 reptiles and amphibians from Angola in the Museu de Lisboa collection (Bocage 1866). Part of this material came from José de Anchieta collected during a zoological expedition in 1864 to Rio Quilo, Cabinda, and the coast of Loango, and other material was collected by Bayão Pinheiro when a military commander in the Duque de Bragança (Calandula) district. After nearly 30 years of subsequent study, during which Bocage published at least a paper a year on the herpetofauna of Portugal's African colonies (see full list in TRIPLOV 2018), he again summarised the Angolan herpetofauna in his mono- 
graphic Herpetology d'Angola et du Congo (Bocage 1895). In this review he more than trebled his previous summary, recording 143 reptile and 39 amphibian species from Angola. Of these Bocage himself described 40 reptile species that are still considered valid, and of which no less that 26 (65\%) had been collected by José de Anchieta, seven of which are still named in his honour. Following Bocage's retirement, herpetological studies at Lisbon were continued, but with less intensity, by Bethencourt Ferreira (1897, 1900, 1903, 1904, 1906), who added a number of additional species to the country list but described only one new snake, Typhlops bocagei (Ferreira 1904), that was later placed in the synonymy of Afrotyphlops lineolatus (Jan, 1864).

George A Boulenger of the British Natural History Museum remains the most prolific herpetologist of all time, and described a remarkable 659 reptiles still recognised today - no less than 5\% of the world's 13,000+ known reptiles (Uetz and Stylianou 2018). In 1905 Boulenger published a note on the amphibians and reptiles collected by WJ Ansorge during a prolonged visit (1903-1905) to Angola (Boulenger 1905). The material included three new species of frogs and a snake, of which two, Rana ansorgii (= Ptychadena ansorgii) and Psammophis ansorgii, were named in the collector's honour. Two years later Boulenger described another three lizards and a frog collected by Ansorge, including the gecko Phyllodactylus ansorgii, the skinks Mabuia ansorgii (Trachylepis sulcata ansorgii) and Mabuia laevis (Trachylepis laevis), and the frog Rana bunoderma (= Ptychadena bunoderma) (Boulenger 1907a), soon followed (Boulenger 1907b) by another new frog from 'Mossâmedes' (actually Catequero, Cunene), Rana cryptotis (= Tomopterna cryptotis). Boulenger (1915) also prepared a List of the snakes of Belgian and Portuguese Congo, Northern Rhodesia and Angola in which he documented 139 snakes for the region, of which only 57 were considered to occur in Angola. This was lower than Bocage's (1895) assessment, but by this time Boulenger had completed his monographic, three volume 'Catalogue' of the World's snakes (Boulenger 1893, 1894, 1896), in which he had synonymised many of Bocage's taxa or shown some to be synonyms. This included Angola's most iconic snake, Vipera heraldica, which Boulenger (1896) surprisingly and incorrectly synonymised with Bitis peringueyi, and Bogert (1940) continued the confusion. There it languished until revalidated by Mertens (1958).

The dramatic discovery of the Giant Sable in Angola early in the twentieth century led to numerous expeditions to collect them as hunting trophies or taxidermy specimens for European and American museum dioramas. Some expeditions collected additional fauna, although the herpetological collections of the Vernay Angola Expedition (VAE 1925) seem to have been plagued by poor documentation. Although various specimens were incorporated in diverse taxonomic reviews, no publication dedicated to the full herpetological results was produced. Bogert (1940) incorporated 202 VAE snakes into his review of African snakes, but 10 species and $42(21 \%)$ specimens lacked detailed locality information and were simply listed as from 'Angola'. Three new snakes were described from Angolan material: Vernay's File Snake (Mehelya vernayi, = Limaformosa vernayi Broadley et al. 2018) from Hanha, and Cowles' Shield Cobra (Aspidelaps lubricus cowlesi) and the Western 
Banded Spitting Cobra (Naja nigricollis nigricincta) from Munhino. The first two have subsequently been discovered at numerous localities in northern Namibia (Haacke 1981; Broadley and Baldwin 2006), but remain known in Angola only from the type or a few other specimens, respectively. Loveridge (1944) described two new geckos (Afroedura bogerti and Pachydactylus scutatus angolensis) on VAE material, and Stanley et al. (2016) discussed VAE Cordylus material labelled simply as 'Angola' and that they assigned morphologically to a new species, Cordylus namakuiyus, discovered in the Namibe region. The description of at least one other new species from old VAE material is also in preparation (Ichnotropis sp. Branch in prep.).

The main targets of the Pulitzer Angola Expedition (1930-1931) were birds and mammals, but Rudyerd Boulton, who had earlier accompanied the VAE, also collected reptiles and amphibians. Karl Schmidt $(1933,1936)$ documented the reptiles and amphibians, respectively, collected during the expedition from diverse sites in the centre and south of the country. The reptiles included two new species, but Lygodactylus laurae was quickly synonymised when Schmidt realised he had overlooked Bocage's (1896) earlier description of L. angolensis. His description of Rhoptropus boultoni not only honoured Rudyerd's contribution to the collection of Angolan reptiles, but was also the first record of this interesting diurnal rupicolous gecko genus for the country. Two other new subspecies were also described, of which Pachydactylus bibronii pulizerae was latter transferred to Chondrodactylus (Bauer and Lamb 2005), and has also been recently validated as a full species, $C$. pulizerae, that is mainly restricted to Angola but also extends into northern Namibia (Heinz 2011; Ceríaco et al. 2014a). The Angolan Savanna Monitor (Varanus albigularis angolensis) was described by Schmidt (1933) from 'Gaúca, Bihe' (= Zaúca River, Malanje; Crawford-Cabral and Mesquitela 1989). Although additional material had been collected the validity of the morphological diagnosis (small nuchal scales and larger body scales) has not been reassessed, and neither has its genetic affinities.

In 1933-1934 Karl Jordan, an entomologist, collected through northern Namibia and Angola and made well documented collections and published a detailed itinerary of his trip (Jordan 1936). Among these was an important herpetological collection, particularly from scarp forest habitats at Congulo and Quirimbo. These were studied by Parker (1936), who recorded diverse Congo Basin snakes previously unknown from Angola; e.g. Philothamnus heterodermus, Thelotornis kirtlandii, Toxicodryas blandingii, T. pulverulenta, Pseudohaje goldii, Chamaelycus parkeri and Hormonotus modestus, as well as the new wolf snake Lycophidion ornatum.

Swiss zoologist Albert Monard explored Angola during two extensive trips (July 1928-February 1929 and April 1932-October 1933) that resulted in extensive reviews of Angolan birds (Monard 1934), mammals (Monard 1935), reptiles (Monard 1937), and amphibians (Monard 1938). Ceríaco et al. (2016a, b) note that Monard was so inspired by Angolan biodiversity that he unsuccessfully championed for the development of a local Natural History Museum that he offered to direct and manage. His detailed reptile 'Contribution' (Monard 1937) was the first overview of Angolan reptiles subsequent to Bocage's (1895) monograph, and within 
it Monard presented taxonomic updates and also initiated the first attempts to generate a biogeographic overview of the herpetofauna (see section below). He noted that only 19 lizards, 10 snakes and a single terrapin had been added to the reptile fauna of Angola, and he even envisaged (incorrectly!) that most of the knowledge on the subject was complete, and he therefore concentrated on understanding biogeographic patterns. However, eight of the 19 additional lizards and three of the 10 snakes he included had already been synonymised (Boulenger 1915) or subsequently were. Certainly Monard seemed little interested in taxonomy and described relatively few novelties, only one of which may remain valid. The rejected taxa include: the worm lizards Amphisbaenia ambuellensis (= Zygaspis quadrifrons), Monopeltis granti kuanyamarum (= Dalophia pistillum), M. devisi (= Monopeltis anchietae), and M. okavangensis (= M. anchietae); the serpent plated lizard Tetradactylus lundensis (= T. ellenbergeri); and the skink Mabuia striata angolensis. The latter, however, remains problematic and under investigation (Conradie et al. 2016). Marques et al. (2018) provided a replacement name, Trachylepis monardi nom. nov., to stabilise taxonomy.

Throughout the early part of the twentieth century various other publications discussed small collections made by explorers (e.g. Angel 1921, 1923; Mertens 1938). All added new locality records within and for the country, and also described a number of new species (some no longer valid, e.g. Psammophis rohani, Angel 1921). Some reptile discoveries were especially serendipitous, e.g. the discovery of the new lizard species Ichnotropis microlepidota (Marx 1956) based on three specimens all found in the crop of a Dark Chanting Goshawk (Melierax metabates) collected during a bird survey of Mount Moco, that still awaits discovery in the wild!

In 1952-1954 the Hamburg Museum made an expedition to various locations in western Angola to collect mammals and herpetofauna, the most important being numerous additional snake records from forested habitats at Piri-Dembos (= Piri, Cuanza-Norte) (Hellmich 1957a, b). These confirmed, and sometimes added to Parker's (1936) records of snakes from the scarp forest isolates of Congulo and Quirimbo. These included (e.g.): Philothamnus heterodermus, Thrasops flavigularis, Toxicodryas blandingii, T. pulverulenta, Gonionotophis poensis, Pseudohaje goldii, Atheris squamigera and Bitis nasicornis. All are Congo Basin species and form an important biogeographic component of Angolan reptile diversity. Hellmich undertook a follow up expedition in 1954-1955, but his expedition suffered delays in obtaining permits and he missed the wet season activity and therefore shifted his survey to more open habitats in the southern provinces. There he undertook some of the first ecological studies on Angolan reptiles that were briefly discussed in a sixpart series of popular articles on his Angolan travels (Hellmich 1954-1955). On his return he studied the reptile collections of the combined Hamburg expeditions (Hellmich and Schmelcher 1956; Hellmich 1957a, b), but the amphibians were only studied much later (Ceríaco et al. 2014b). As with Monard, Hellmich discovered relatively few taxonomic novelties, i.e. the lizards Gerrhosaurus nigrolineatus ahlefeldti (currently not considered valid) and Agama agama mucosoensis (now a full species; Wagner et al. 2012). 
Between 1950 and 1960 the Belgian herpetologist Raymond F Laurent lived in Rwanda and Katanga (then Belgian colonies) and undertook detailed studies on varied herpetological groups in the Congo Basin, describing numerous new species and subspecies. During this period he studied the herpetological collections of the Museu do Dundo in northeast Angola, made by António de Barros Machado, the museum's director. Summaries of the museum's snake collections appeared first (Laurent 1950, 1954), followed by another report on Dundo material including Machado's extensive herpetological collection from the arid southwest region of the country (Laurent 1964). This was completed after Laurent had moved to the United States (1961) and the report described a number of new Angolan species, including Bogert's Speckled Western Burrowing Skink (Typhlacontias bogerti), two Namib Day geckos (Rhoptropus taeniostictus and $R$. boultoni montanus), and finally Hellmich's Wolf Snake (Lycophidion hellmichi), based (in part) on material collected during the Hamburg expeditions. It also included additional information of many previously poorly known species, as well as making ecological observations. It set a new standard for herpetological research in the area, but sadly was the final major Angolan herpetological work of the colonial period. Laurent did not study the historical collections in the Museu de Lisboa, and therefore did not re-assign Bocage's original material to his new taxa or identify significant new distribution records. This was unfortunate as he was one of the last herpetologists working on the Angolan herpetofauna before the disastrous fire that destroyed (1978) the collections that Bocage had studied, as well as much of his correspondence with collectors and fellow researchers. Manaças reported on collections of lizards (Manaças 1963), snakes (Manaças 1973), and venomous snakes (Manaças 1981) from Angola.

\section{Bringing Knowledge of Angolan Reptiles into the Modern Era}

Awareness of the interesting reptiles of the Angolan Namib region started incidentally following expeditions in the 1950 s by the enthusiastic entomologist Charles Koch of the Transvaal Museum (TMP, now the Ditsong Natural History Museum, Pretoria, South Africa). Koch did much to inventory the amazing diversity of the tenebrionid beetle fauna of the Namib Desert, and much of his collecting involved walking at night in the desert with a pressure lamp. In addition to his numerous beetle discoveries Koch also collected many nocturnal and terrestrial reptiles, particularly geckos. These he gave to his colleague at the TMP, the Curator of Lower Vertebrates Vivian FitzSimons. Koch visited the northern Namib in Angola on four occasions (1951-1957), accompanied on the last trip by the Swedish zoologists Lundholm and Rudebeck. The herpetological collections during these trips were significant, and FitzSimons (1953, 1959) described a new genus of plated lizard Angolosaurus (now subsumed within Gerrhosaurus) as well two new species, Pachydactylus caraculicus and Prosymna visseri. Unreported, however, were many of Koch's numerous other reptile discoveries, including new records of the iconic Namib Web-footed Gecko (Palmatogecko rangei, now included in Pachydactylus) 
in 1951 and 1954, then unknown from the Angolan Namib region. Laurent (1964) described the new Angolan Namib Day Gecko Rhoptropus taeniostictus from Angola, although nine specimens had already been collected by Koch during his trips, but remained undescribed. Also unrecorded were nine specimens of Pachydactylus scutatus angolensis from Lungo, Lucira and São Nicolau, the first collected since the description of the species by Loveridge (1944), and also 13 specimens of Chondrodactylus fitzsimonsi, at the time known from only one Angolan specimen (Pico Azevedo, Schmidt 1933).

In 1964 Wulf Haacke, born in Namibia, became the then Transvaal Museum's herpetologist with a special interest in the arid western areas of southern Africa. In March-April 1971 he undertook his first trip to Angola, concentrating on the northern extension of the Namib Desert into southwestern Angola. A follow up trip in April-June 1974 targeted specific genera to confirm the northern range limits and taxonomic status of Cordylus, Cordylosaurus, Gerrhosaurus, Pachydactylus, Afroedura and Rhoptropus. Both trips were exceptionally successful resulting in over 2000 specimens, the largest herpetological collections ever assembled by one researcher in Angola. Although the amphibian collections made during these trips were reviewed by Poynton and Haacke (1993), the vast majority of the numerous new and rare reptiles contained in these collections were never formally published. Haacke's second trip in 1974 was designed in particular to collect new material for his proposed thesis and revision of Rhoptropus. Prior to this trip, and excluding Koch's undescribed material, less than 30 specimens of Rhoptropus were known from Angola (Bocage 1895; Parker 1936; Mertens 1938; Laurent 1964). At the end of Haacke's surveys the Transvaal Museum held 650 specimens of the genus, included nearly 250 specimens of $R$. barnardi from over 25 localities, nearly 50 specimens of $R$. biporosus, and seven of $R$. afer. At the time R. barnardi in Angola was known from very few specimens (Bocage 1895; Schmidt 1933; Parker 1936; Laurent 1964) and $R$. biporosus was unknown in Angola and restricted to northern Namibia. The status of $R$. afer in Angola was particularly confused. Bocage's (1895) knowledge of Namib Day geckos (Rhoptropus) seems to have been limited, and he considered specimens from diverse localities from coastal Moçâmedes and the interior to Capangombe to all be applicable to $R$. afer Peters 1869. However, he noted that his material had 6-8 preanal pores whilst $R$. afer, as Peters (1869) had correctly recorded, had none. Schmidt also recorded $R$. barnardi for the first time from Angola, noting numerous other specimens from the Moçâmedes region in the British and Zoologisches museums that agreed with $R$. barnardi. These may have been the source of Bocage's confusion. The few recent records of Angolan R. afer have all been restricted to the vicinity of the Cunene River mouth, and it is evident that Bocage's material from further north was not based on true $R$. afer.

Due to the limited access to Angola during the protracted civil war the TM expeditions to Angola were curtailed, and for the next 34 years studies on Angolan reptiles were based on museum material collected earlier. Details of some of the geckos collected by the TM expeditions were incorporated into Haacke's studies on the burrowing geckos of southern Africa, which included the first records for Angola (Haacke 1976a) for the Palmatogecko rangei and Kaokogecko vanzyli (both now included in 
Pachydactylus), and by implication Colopus (= Pachydactylus) wahlbergii, known to Haacke (1976b) from three specimens (TM 38526-28) from the Angola-SWA border, 18 degrees E). The bizarre and iconic Plume-tailed Gecko Afrogecko plumicaudus, collected during Haacke's 1971 trip, was of problematic taxonomic affinities and not described until much later (Haacke 2008). Its true affinities, however, were finally resolved later when fresh material was available for genetic analysis and it was placed in the monotypic genus Kolekanus (Heinicke et al. 2014). The 64 burrowing skinks of the genus Typhlacontias collected during these expeditions also formed an integral part of Haacke's (1997) revision of the genus, and which led to the recognition of a long overlooked Namib species, T. johnstonii, previously confused (Bocage 1895; Monard 1937) with T. punctatissimus, and described from Porto Alexandre (=Tômbwa) at the northern limit of its range. A new Angolan species, T. rudebecki, was also described, based on a single specimen collected from São Nicolau during Koch's 1956 expedition. Laurent's (1964) species T. bogerti was treated as a northern subspecies of the Speckled Burrowing Skink, T. punctatissimus bogerti (Haacke 1997). A number of other new Angola records were discovered by Haacke during his trips. The rupicolous gecko Pachydactylus oreophilus, described from northern Namibia (McLachlan and Spence 1967), was known only from the types until Haacke discovered similar material from numerous localities in southwest Angola. No additional Angolan material was collected until the Huntley expedition in the region in 2009 (see below), when it was realised that Angolan material was not conspecific with Namibian $P$. oreophilus. The status of the Angolan material is currently being investigated (Branch et al. in prep.). Haacke also collected the first records of true $P$. scutatus from Angola, as well as additional P. angolensis (Branch et al. 2017). Finally, Broadley (1975) referred some small skinks collected by Haacke to Trachylepis lacertiformis, creating a zoogeographic enigma as the nominotypic population of this small skink is restricted to the lower Zambezi River valley. Fuller details of the Koch and Haacke collections and other recent material will be incorporated into a full review of the herpetofauna of the Angolan Namib region (Branch in prep.).

Legless burrowing worm lizards (Amphisbaenidae) are rarely found due to their ability to burrow deep underground. Carl Gans (1976) described three new species from Angola, including Monopeltis luandae based on fresh (1971) and historical (1892) material from the Luanda region, and $M$. perplexus on material from the Vernay-Angola expedition collected from 'Hanha or Capelongo' in 1925. Similarly, Gans (1976) re-assessed old and new material when describing Dalophia angolensis from Calombe near Vila Luso (= Luena), and reassigned specimens identified as M. ellenbergeri, and then as M. granti transvaalensis (Monard 1937), to D. angolensis. None of Gans' three new species had been rediscovered in the intervening 40+ years until recently, when $M$. luandae was rediscovered from near the type locality (Branch et al. 2018). In a companion paper that radically changed understanding of the taxonomy of worm lizards in the southern half of Africa, Broadley et al. (1976) revised the genera Monopeltis and Dalophia. The revision of Broadley et al. (1976) affected most of the early names applied to Angolan worm lizards. The first large worm lizard described from Angola was Lepidostsernon (Phractogonus) anchietae Bocage 1873, from 'Humbe, dans l'intérior de Mossamedes', later transferred to the 
genus Monopeltis (Boulenger 1885). Broadley et al. (1976) relegated Monard's (1937) species M. okavangensis and M. devisi to M. anchietae, which is now known to have a wider range in northern Namibia and adjacent Botswana. Monopeltis vanderysti vilhenai, described by Laurent (1954) from Dundo, Angola, was not recognised by Broadley et al. (1976) and returned to $M$. vanderysti, which is widely distributed in the Congo region. The Dundo specimen remains the only Angolan record of the species. Monopeltis capensis in Angola was first recorded by Bocage (1873), and later by Monard (1937). Although provisionally placed in the M. capensis capensis Group B (Broadley et al. 1976), with a wide range through the Kalahari region (Northern Cape, South Africa, through Botswana to southern Angola), it was later treated as a separate species, M. infuscata Broadley 1997a. Monard's (1937) species Monopeltis granti kuanyamarum, described from a single specimen from Mupanda, was transferred to Dalophia pistillum (Broadley et al. 1976). The only Angolan specimen of Dalophia ellenbergeri was collected whilst trench digging during hostilities at Cuito Cuanavale (Branch and McCartney 1992; Broadley 1997b). Gray (1865) described Dalophia welwitschii from Pungo Andongo, and this has not been rediscovered. It is the type species for the genus Dalophia, and Gans (2005) was obviously in error when treating it as M. welwitschii and yet still continuing to recognise Dalophia. A phylogeny of African amphisbaenids (Measey and Tolley 2013), albeit based on poor taxon sampling, recovered Monopeltis and Dalophia as monophyletic clades, supporting the use of Dalophia welwitschii.

Two species of round-headed worm lizards of the genus Zygaspis are now known to occur in southeast Angola, but the genus was unknown to Bocage from Angola, and the first record from the country was Monard's (1931) description of Amphisbaena ambuellensis from 'Chimporo' (= Tchimpolo). This was subsequently synonymised with A. quadrifrons by Loveridge (1941) with some misgivings, and subsequently transferred to Zygaspis by Alexander and Gans (1966). It remained known only from Monard's material for many years, but has recently been collected in southern Angola (Conradie et al. 2016, Baptista et al. in prep.), and the availability of Monard's ambuellensis for this material is being reassessed. More recently, Laurent (1964) recorded A. q. capensis from Alto Chicapa in northeast Angola, which was shown to be the new species Zygaspis nigra by Broadley and Gans (1969). This small black worm lizard is near endemic to eastern Angola, with records from adjacent Zambia (Kalobo, Broadley and Gans 1969; Ngonya Falls, Pietersen et al. 2017) and Namibia (Katima Mulilo, Broadley and Gans 1969). Recent material is known from the Okavango catchment (Conradie et al. 2016).

Following the cessation of hostilities, modern biodiversity surveys were initiated by Brian Huntley with the multinational SANBI/ISCED/UAN Angolan Biodiversity Assessment and Capacity Building Project (Huntley 2009). Surveys were undertaken by botanists and zoologists in various habitats between Lubango and the Cunene River, and 15 Angolan students were involved in fieldwork and training sessions. The immediate reptile highlights of the survey involved the discovery of two new species of the lacertid Pedioplanis (Conradie et al. 2012a), two specimens of the rare Shovel-snout Snake Prosymna visseri were collected at Espinheira, Iona National Park, only the 5th and 6th Angolan specimens since its description 
(FitzSimons 1959); the 1st record of the Namib Wolf Snake (Lycophidion namibianum) from Angola, again at Espinheira; the southernmost records of the newlydescribed Plume-tailed Gecko (Afrogecko plumicaudatus Haacke 2008) that allowed its generic assignment to later be readjusted; and topotypic material of the rare chameleon (Chamaeleo anchietae) were collected around Estação Zootécnica. This chameleon has an unusual, disjunct distribution with scattered populations (treated as separate subspecies by Laurent 1951) from the Upemba region, Democratic Republic of the Congo (DRC) and Udzungwa Mountains, Tanzania. The status of these disjunct $C$. anchietae populations is currently under investigation (Branch et al. in prep.). A new species of reed frog, Hyperolius chelaensis, completed the new discoveries (Conradie et al. 2012b). Following the success of the 2009 survey, another expedition was organised in 2011 to Lagoa Carumbo, the second-largest Angolan freshwater lake situated in Lunda Norte Province (Huntley and Francisco 2015). The herpetological results were summarised by Branch and Conradie (2015). Significant herpetological discoveries included the discovery of at least two new species of frog, one described (Hyperolius raymondi Conradie et al. 2013), and the description of the other (Amnirana sp.) is in preparation (Jongsma et al. 2018), and also the first record for Angola (Branch and Conradie 2013) of the Banded Water Cobra (Naja annulata). Other reports include new insights into the distributions of venomous snakes, such as Jameson's Green Mamba, Dendroaspis jamesoni (Vaz Pinto and Branch 2015) and the Gaboon Adder, Bitis gabonica (Oliveira et al. 2016), as well as a recent summary of Angolan venomous snakes (Oliveira 2017).

The unique World Heritage site of the Okavango Delta is situated in Botswana, but depends on the Okavango drainage, which arises and is almost entirely contained within southeastern Angola. During the last six years a series of international collaborative surveys have been undertaken to explore this poorly known region of southeast Angola, and to understand the hydrology and biodiversity of the Okavango drainage. The first surveys were organised by the Okavango River Basin Water Commission (OKACOM), in accord with the Angolan National Action Plan for the Sustainable Management of the Cubango/Okavango River Basin (OKACOM 2011), and occurred in the lower catchments of the Cubango and Cuito rivers (Brooks 2012, 2013). More recent surveys (2015-2018) formed part of the ongoing National Geographic funded Okavango Wilderness Project (NGOWP 2018), which have intensely surveyed the source lakes of the major Okavango tributaries in an unexplored region where the headwaters of the Cuanza, Zambezi and Okavango basins meet. The herpetological results of the OKACOM surveys (2012-2013) and first phase of the NGOWP surveys were presented by Conradie et al. (2016), who also reviewed the region's herpetofauna. In total 67 reptiles species are now known from the region, comprising 38 snakes, 32 lizards, five chelonians, and a single crocodile (NGOWP 2018). Three reptiles new for Angola, including Causus rasmusseni (although the specific status of this taxon still requires genetic confirmation), Acontias kgalagadi kgalagadi and Panaspis maculicollis were discovered (Conradie and Bourquin 2013; Medina et al. 2016). The results of more recent surveys (20162018) were presented (Conradie et al. 2017) and fuller details are being prepared for publication, and online species lists are planned for public access. 
Contemporaneous with the above surveys a number of other Angolan biodiversity initiatives began. In partnership, the Kimpa Vita University in Uíge and Dresden University, Germany, undertook herpetological surveys of Serra do Pingano, Uíge Province, discovering diverse tropical Congo Basin species (Ernst 2015), including two frogs previously unrecorded for Angola (Ernst et al. 2014, 2015). In addition the California Academy of Sciences in conjunction with the National Institute of Biodiversity and Conservation Areas and the Ministry of the Environment of Angola (MINAMB/INBAC) initiated an ongoing Atlas of Angolan amphibian and reptiles (Marques et al. 2014, 2018). Various areas have been surveyed and preliminary results published in the scientific and popular literature (Ceríaco et al. 2014a, b, 2016a, b, 2018b). As part of the Southern African Science Service Centre for Climate Change and Adaptive Land Management program (SASSCAL) the Instituto Superior de Ciências da Educação da Huíla (ISCED), Lubango, has been undertaking herpetofaunal monitoring at several areas in Huíla Province and elsewhere in Angola (Baptista et al. 2018, 2019), with emphasis on the escarpment. A herpetofaunal archive is also being developed at ISCED.

Angolan citizen science is in its infancy, but the FaceBook site Angola Ambiente is a public group where members post observations (https://www.facebook.com/ groups/1045499302182009/). It is designed "to raise awareness of the fantastic fauna and flora of this magnificent country", and requests observations with detailed locality data. It includes irregular lists of sightings with locality details in support of mapping initiatives.

\section{Checklist of Angolan Reptiles}

\section{How Many Species?}

The first attempt to summarise the herpetofauna of Angola was undertaken by JV Barbosa du Bocage (1866), who listed 50 reptile species from Angola in the Museu de Lisboa collection, including 23 snakes, 21 lizards, four chelonians, and one crocodilian. After nearly 30 years of study he again summarised the Angolan herpetofauna in his monographic Herpetology d'Angola et du Congo (Bocage 1895) in which he listed 143 reptile and 39 amphibian species from the country. Of these Bocage had described 37 of the taxa (although not all are now recognised). During two trips to Angola (1928-1929 and 1932-1933) the Swiss collector Albert Monard made important collections of amphibians and reptiles. In his monograph (Monard 1937) he presented an updated checklist of Angolan reptiles, listing 169 reptile species in 10 families and 28 genera. There has been no subsequent updated and checklist of the country's reptiles, although Blanc and Fretey (2002) noted a total of 257 Angolan reptile species and published a breakdown of its composition. However, no species list was included and therefore it is impossible to assess the accuracy or the validity of the species included. In contrast, the online Reptile Database (Uetz et al. 2018, as on 14 October 2018) currently generates a list of 255 reptiles for Angola, 
but unfortunately although close to the existing count, it is inaccurate in numerous respects. Some species have been included that are unrecorded from the country but may occur in the country (e.g. a snakes from the Congo Basin Calabaria reinhardti, Namibian Lygodactylus lawrencei, etc.). Moreover, many other species are duplicated and listed under both their historical and current taxonomic assignments (e.g. Agama hispida $=$ A. aculeata, Chamaesaura macrolepis $=$ Ch. miopropus, Cordylus cordylus $=C$. namakuiyus, $C$. vittifer $=C$. machadoi, etc.) These inaccuracies have been discussed in the recent Atlas and being rectified (see Marques et al. 2018 Appendix Table A2).

Currently (as of mid-2018), there are 278 reptile species recorded from Angola, comprising 15 chelonian, three crocodilian, 132 lizard and 128 snake species. Table 13.1 details the historical growth of knowledge of reptile diversity in Angola based on summaries in Bocage (1866, 1895), Monard (1937), and this study. Table 13.2 summarises the number of genera, species, and endemic taxa in the major reptile groups in Angola. Updated checklists of the major reptile groups, including details of common and scientific names, historical scientific names used by Bocage (1895) for the current taxa, as well as their endemic and conservation status are summarised in: Appendix 1 - chelonians; Appendix 2 - lizards; and Appendix 3 - snakes. Contained within these checklists are 43 Angolan species named by Bocage, i.e. $15.5 \%$ of the current reptile diversity. This is less than the $25.9 \%$ (37 of 143) in Bocage's (1895) summary, but no other researcher has described more from Angola.

Table 13.1 Historical development of reptile diversity in Angola based on summaries in Bocage (1866, 1895), Monard (1931), and this study

\begin{tabular}{|c|c|c|c|c|}
\hline \multirow[b]{2}{*}{ Group } & \multicolumn{2}{|c|}{ Bocage } & \multirow{2}{*}{\begin{tabular}{|l} 
Monard \\
1937
\end{tabular}} & \multirow{2}{*}{\begin{tabular}{|l|} 
This study \\
2018 \\
\end{tabular}} \\
\hline & 1866 & 1895 & & \\
\hline Snakes & 23 & 71 & 81 & 128 \\
\hline Lizards & 21 & 59 & 78 & 132 \\
\hline Chelonians & 4 & 8 & 9 & 15 \\
\hline Crocodilians & 2 & 1 & 1 & 3 \\
\hline Total $^{\mathrm{a}}$ & 50 & 139 & 169 & 278 \\
\hline
\end{tabular}

aThis includes 'species' known at the time of Bocage and Monard, some of which may have later been relegated to synonymy (see discussion on Monard's list)

Table 13.2 Summary of the taxonomic diversity and endemicity of the reptiles of Angola

\begin{tabular}{l|c|c|c}
\hline Group & Genera & Species & Endemic \\
\hline Chelonians & 11 & 15 & 0 \\
\hline Crocodilians & 3 & 3 & 0 \\
\hline Lizards & 40 & 132 & 27 \\
\hline Snakes & 49 & 128 & 6 \\
\hline Total & $\mathbf{1 0 3}$ & $\mathbf{2 7 8}$ & $\mathbf{3 3}$ \\
\hline
\end{tabular}




\section{Recent Discoveries}

In the last decade, and resulting from the burgeoning scientific interest in Angola, biodiversity surveys have led to the description of numerous new species and the validation of the specific status of others. Perhaps the most exciting was the long delayed description of the beautiful and bizarre Plume-tailed Gecko (Afrogecko pulumicaudus Haacke 2008) from the Angolan Namib region. Other novelties included the description of the lacertids Pedioplanis haackei and P. huntleyi (Conradie et al. 2012a and the cordylid Cordylus namakuiyus (Stanley et al. 2016). Some subspecies were validated as full species, including the geckos $R$. boultoni benguellensis and $R$. boultoni montanus (Ceríaco et al. 2016a) and the snake Psammophylax rhombeatus ocellatus (Branch et al. 2019), as well as the revival of the skink Trachylepis damarana from the synonymy of T. varia (Weinell and Bauer 2018). Some species, e.g. Philothamnus nitidus loveridgei, however, have been shown to lack genetic support for recognition (Engelbrecht et al. 2018) and are now not recognised.

In addition, preliminary studies have revealed numerous problematic specimens and populations that demonstrate the existence of cryptic, previously synonymised species or unnamed taxa awaiting description in numerous genera. Geckos Hemidactylus, Rhoptropus (Ceríaco et al. 2016a; Bauer and Kuhn 2017), Afroedura (Branch et al. 2017), and various Pachydactylus groups (Branch et al. 2017; Ceríaco et al. 2016a; Heinz 2011); within the lacertids Nucras, Pedioplanis and Heliobolus (Branch and Tolley 2017); and a skink in the Trachylepis varia complex (Weinell and Bauer 2018). The descriptions of at least a dozen new species in these genera are in preparation. Ceríaco et al. (2016b, 2018b) signalled the presence of a new skink (T. cf. megalura) from Cangandala National Park. Snake-eyed skinks (Panaspis wahlbergii-maculilabris complex) have been shown to include numerous cryptic species in southern and east Africa (Medina et al. 2016). Records of P. wahlbergii in Angola are therefore also likely to represent taxonomic novelties. It is also likely that genetic studies will further validate a number of other lizard taxa currently treated as subspecies, e.g. Ichnotropis bivittata palida and Trachylepis bayoni huilensis, as full species. Moreover, the rare gecko Afrogecko ansorgi, described by Boulenger (1907a), as Phyllodactylus ansorgi and not collected again for nearly 100 years, was recently rediscovered and a re-assessment of its generic status is in preparation. In addition, ongoing surveys of the Angolan Okavango Project continue to confirm new species records for Angola, including most recently Pachydactylus wahlbergii (G Neef pers. comm. July 2018), previously assumed to enter southern Angola based on material collected on the Angolan-Nambian border in the 1970s (Haacke 1976b). Cryptic diversity in snakes is also being unravelled, and African forest cobras have been shown to include five species (Wüster et al. 2018), of which two enter Angola, whilst Angolan house snakes (Boaedon) is expected to comprise at least eight species, with four potential new country records, i.e. B. fuliginosus, B. radfordi, B. virgatus and B. mentalis (the latter signalled as a valid species by Kelly et al. 2011, and will be formally revived for western arid populations from South Africa to southwest Angola), revival from synonymy of two 
Bocage names for Angolan endemics, i.e. B. angolensis and B. variegatus, and two additional taxonomic novelties (Hallermann et al. personal communication).

\section{Overview of Reptile Diversity}

\section{Chelonians}

This ancient lineage of reptiles has relatively little global diversity and includes the greatest proportion of threatened reptiles, particularly in Asia. They are relatively poorly known in Angola, and their diversity is discussed below. The first sea turtle to swim in the early South Atlantic, after the separation of Africa and South America 90 Million years ago, was the extinct chelonian Angolachelys mbaxi, discovered in Angola in 2009 near the village Iembe, Bengo Province (Mateus et al. 2009). Five of the seven species of sea turtles in the world have been recorded from Angolan waters (Carr and Carr 1991), although only four occur regularly. They include (in decreasing order of abundance): Olive Ridley Sea Turtle (Lepidochelys olivacea), Leatherback Sea Turtle (Dermochelys coriacea), Green Sea Turtle (Chelonia mydas), Loggerhead Sea Turtle (Caretta caretta), and Hawksbill Sea Turtle (Eretmochelys imbricata). Although early surveys (2000-2006) indicated the absence of Hawksbill in Angolan waters (Weir et al. 2007), juveniles were recently recorded in the Soyo and Cabinda region (Morais 2008, 2016). These may still be vagrants in Angolan waters (TTWG 2017) as Hawksbills forage on coral reefs which are absent in Angola. Nesting in Angolan waters has only been confirmed for Green, Olive Ridley and Leatherback sea turtles, and occurs during SeptemberMarch, peaking in November-December in the north and a month later in the south (Morais 2017). It is widespread for the Olive Ridley, but restricted mainly to the south for the Green Sea Turtle. The latter remains common in the Cunene River estuary where adults and juveniles feed and also escape the cold waters of the Benguela Current (Elwen and Braby 2015). The giant Leatherback nests primarily in the warmer north, with little activity south of Benguela. The Angolan population (approximately 1000 in 2005-2016, Morais 2016) forms the southern part of the major Gabon nesting grounds, where 6000-7000 females breed annually (Billes et al. 2006). Sea turtles face numerous threats, including by-catch and drowning in trawler fishing nets, the collection of nesting females and their eggs for food, and disturbance of the nest sites by beach activities, etc. (Morais et al. 2005; Morais 2008; Weir et al. 2007). The Projecto Kitabanga of Universidade Agostinho Neto (https://www.facebook.com/Kitabanga/) is involved in research and public education of Angolan sea turtles.

Only three land tortoises are recorded for Angola. The Leopard Tortoise (Stigmochelys pardalis) is restricted to the southwest, with all records occurring below the escarpment south of Benguela and along the Cunene valley. Bell's Hingeback Tortoises (Kinixys belliana) is considered widespread in Angola (TTWG 2017), and Kinixys material from central and eastern Angola were confirmed as this 
species in a molecular phylogeny of the genus (Kindler et al. 2012). Although material from Capanda Dam has been referred to Kinixys spekii (Ceríaco et al. 2014a), this species is not currently considered to occur in the country (TTWG 2017), but is known from the Zambezian region of Namibia and the Ikelenge pedicle of northwest Zambia. The Forest Hinge-back Tortoise (Kinixys erosa) occupies moist forests of the Congo basin and West Africa, but only enters Angola in the extreme northeast (Dundo, Laurent 1964) and the Cabinda enclave (Bocage 1895).

The Nile Soft-shelled Terrapin (Trionyx triunguis) is restricted to the coastal region, entering the estuaries and lower stretches of the major rivers. It tolerates sea water and grows to over a metre in length. Populations in the eastern Mediterranean and lower Nile River are threatened, and its status in Angola is poorly known, but is known from the coastal region and with populations in the Cunene River mouth and extending some distance upstream in the Cuanza River. Aubry's Soft-shelled Terrapin (Cycloderma aubryi) was recorded once from Cabinda (Peters 1869), but there are no recent records. Trade in chelonians, particularly soft-shelled terrapins for food in Asia, has pushed many species to the brink of extinction (TTWG 2011), and involvement in Africa is confirmed by the discovery of a turtle butchery on Lake Malawi (Face of Malawi 2013) and the recent confiscation of a large T. triunguis in a shopping mall in Luanda (Arruda 2018). All other Angolan terrapins have hard shells and are restricted to fresh water ecosystems. They withdraw the head into the shell sideways and are represented by the Pelomedusidae in Africa, including the genera Pelomedusa and Pelusios. Although Bocage (1866) listed the forest species Pelusios gabonensis from Cabinda and Duque de Bragança in his first review of Angolan reptiles, the species was subsequently omitted (Bocage 1895). However, it was subsequently recorded from Dundo (Laurent 1964), and mapped to enter extreme northwest Angola south of the Congo River (TTWG 2017), but no documentation supporting this is presented. It was not recorded at Soyo (W Klein pers. comm.), although Western Hinged Terrapin (Pelusios castaneus) was common. The most widespread Angolan terrapins are Pelusios nanus, P. bechuanicus and P. rhodesianus in the extensive wetlands of eastern Angola (Conradie et al. 2016; TTWG 2017).

\section{Crocodilians}

Of the three crocodilians that occur in Angola, only the Nile crocodile (Crocodylus niloticus) is widespread, being absent only from the southwest although occurring in the lower Cunene River. The remaining two species are both denizens of the Congo Basin and have only a peripheral presence in Angola. The Sharp-snouted Crocodile (Mecistops cataphractus) in Angola had been discussed by Machado (1952), who noted an unusual early record from Lunda and others from Dundo, later confirmed by Laurent (1964). Recent studies (Shirley et al. 2014) have found significant molecular and morphological support for two divergent taxa in Mecistops one distributed entirely in West Africa and the other in Central Africa. As the type 
locality is Senegal, West African populations would keep the name and Congo Basin and Angolan populations have been considered to represent an undescribed species (Shirley et al. 2014), and was subsequently described as a new species, Mecistops leptorhynchus (Shirley et al. 2018). The Dwarf Crocodile (Osteolaemus tetraspis) is known from nineteenth century of records from the Cabinda enclave (Bocage 1866; Peters 1877), but no confirmed records exist for the natural occurrence of the species south of the Congo River (Eaton 2010). Ceríaco et al. (2018a) discuss a problematic specimen collected in the lagoon at Luanda that they consider to be indicative of an unknown population in the Cuanza River drainage and also the first record of $O$. osborni for Angola. However, the specimen's identity was not confirmed by genetic monophyly, and its presence in Angola may also result from an escapee brought to Luanda for the bushmeat trade. As with Mecistops recent genetic studies indicate the existence of at least three species within the Osteolaemus tetraspis complex (Eaton et al. 2009), but the taxonomic identity of Cabinda and the putative Cuanza Osteolaemus populations require further study.

\section{Squamates}

Scaled reptiles (Squamata) form the major component of reptile diversity (PincheiraDonoso et al. 2013), with over 10,000 species currently recognised, of which over $60 \%$ are lizards. Reflecting this, lizards are also the dominant component of the Angolan reptile diversity and are the group in which most recent discoveries have been made (see above).

The 132 species of Angolan lizards are currently contained in nine families, with skinks (Scincidae) containing the greatest diversity. This contrasts with Namibia (Herrmann and Branch 2013) and South Africa (Branch 2014) where geckos form the greatest component of lizard diversity and endemicity (Table 13.3). It is likely that the current dominance of skinks in Angola is an artefact of our present knowledge. Most skinks are diurnal and active and therefore more easily discovered. Cryptic diversity has already been identified in certain Angolan gecko genera (e.g. Afroedura, Pachydactylus and Rhoptropus, see above), and the discovery of these and others is predicted to also promote geckos to dominance in diversity and endemicity in the Angolan reptile diversity. The evolutionary centre for girdled lizards (Cordylidae) occurs in southern African (Stanley et al. 2016), but the family is relatively poorly represented in Angola. Although it is unlikely to reach the species or generic diversity of even Namibia, there are indications that the diversity of rupicolous Cordylus in the escarpment and central uplands is under-represented (e.g. Stanley et al. 2016), and that rediscoveries and further new species await discovery and description.

The families Agamidae, Chamaeleonidae, Gerrhosauridae and Varanidae all have limited diversity in Angola, as do the last two families throughout Africa. Blue-headed tree agamas have been revised (Wagner et al. 2018), with populations from northern Namibia, Angola and northwest Zambia now referred to the revived Acanthocercus cyanocephalus. However, it is evident that current species boundaries 
Table 13.3 Comparison of diversity and endemicity of Angolan and South African Squamates (excluding Chelonia), by genera (Gen.), species (Spp.), subspecies (Sub.), and endemism (End.)

\begin{tabular}{l|l|l|l|l|l|l}
\hline \multirow{2}{*}{ Family } & Angola & \multicolumn{7}{l}{ South Africa } \\
\cline { 2 - 7 } & Gen. & Spp. & End. & Gen. & Sp. & End. \\
\hline Lizards & 8 & 34 & 8 & 12 & 89 & 55 \\
\hline Gekkonidae & 2 & 7 & 2 & 2 & 7 & 0 \\
\hline Agamidae & 2 & 5 & 0 & 2 & 19 & 15 \\
\hline Chamaeleonidae & 4 & 8 & 0 & 5 & 13 & 6 \\
\hline Gerrhosauridae & 4 & 5 & 2 & 10 & 53 & 38 \\
\hline Cordylidae & 2 & 45 & 6 & 7 & 62 & 32 \\
\hline Scincidae & 12 & 15 & 6 & 8 & 29 & 9 \\
\hline Lacertidae & 6 & 11 & 3 & 4 & 12 & 2 \\
\hline Amphisbaenidae & 3 & 2 & 0 & 1 & 2 & 0 \\
\hline Varanidae & 1 & $\mathbf{1 3 2}$ & $\mathbf{2 7}$ & $\mathbf{5 1}$ & $\mathbf{2 8 6}$ & $\mathbf{1 5 7}$ \\
\hline subtotal & $\mathbf{4 0}$ & & $\mathbf{( 2 0 . 5 \% )}$ & & & $\mathbf{( 5 4 . 9 \% )}$ \\
\hline & & & & & &
\end{tabular}

Snakes

\begin{tabular}{|c|c|c|c|c|c|c|}
\hline Leptotyphlopidae & 2 & 5 & 2 & 3 & 10 & 3 \\
\hline Typhlopidae & 2 & 8 & 1 & 3 & 7 & 0 \\
\hline Pythonidae & 1 & 3 & 0 & 1 & 2 & 0 \\
\hline Colubridae & 14 & 31 & 0 & 9 & 16 & 0 \\
\hline Natricidae & 2 & 4 & 0 & 1 & 2 & 0 \\
\hline Lamprophiidae $^{a}$ & 15 & 39 & 2 & 17 & 42 & 3 \\
\hline Atractaspididae & 6 & 11 & 0 & 6 & 16 & 2 \\
\hline Elapidae & 5 & 14 & 0 & 6 & 18 & 1 \\
\hline Viperidae & 3 & 13 & 1 & 2 & 14 & 4 \\
\hline \multirow[t]{2}{*}{ subtotal } & \multirow[t]{2}{*}{50} & \multirow[t]{2}{*}{128} & 6 & \multirow[t]{2}{*}{48} & \multirow[t]{2}{*}{127} & 13 \\
\hline & & & $(4.7 \%)$ & & & $(10.2 \%)$ \\
\hline \multirow[t]{2}{*}{ TOTAL } & \multirow[t]{2}{*}{95} & \multirow[t]{2}{*}{260} & 33 & \multirow[t]{2}{*}{109} & \multirow[t]{2}{*}{413} & 170 \\
\hline & & & $(12.7 \%)$ & & & $(41.2 \%)$ \\
\hline $\begin{array}{l}\text { Angola/South } \\
\text { Africa }\end{array}$ & $83 \%$ & $63 \%$ & & & & \\
\hline
\end{tabular}

${ }^{a}$ Excludes additional Boaedon species (Hallerman et al. in prep.)

in Agama and Acanthocercus do not full reflect Angolan agamid diversity. The remaining families, Lacertidae and Amphisbaenidae, are relatively well represented in Angola, with worm lizard diversity in Angola (three genera, 11 species) second only to that in South Africa (12) for diversity in Africa. Most are associated with the sands of the Kalahari Basin, or in secondary deposition in the coastal zone of South Africa and southern Mozambique. The role of river capture and hydrological changes associated with nascent rifting on fossorial reptiles awaits fuller study. Lacertid diversity in Angola (13 species) is reduced relative to South Africa (29) and Namibia (24), but is known to be under-represented and recently described Pedioplanis species (Conradie et al. 2012a), and recently discovered cryptic diversity in other lacertid genera (Branch and Tolley 2017; Conradie et al. 2016) will increase species numbers in the family. A number of additional tropical lacertids may also enter the northern regions of Angola (see below). 
There are several aspects of Angolan reptile diversity that stimulate interest. The first is the absence of an endemic radiation of chameleons within Angolan forest refugia. African countries with the highest chameleon diversity (Tilbury 2018), i.e. South Africa and Tanzania, have largely endemic radiations of chameleons (Kinyongia and Rhampholeon in Tanzania, Bradypodion in South Africa). All three genera are absent from Angola, where only Chamaeleo and Trioceros occurs. Greater knowledge of the history of forest habitats in Angola may give insight as to the absence of a forest chameleon radiation. Sandy habitats in arid southwest Angolan include a radiation of skinks of the genera Sepsina and Typhlacontias that have reduced limbs, serpentine locomotion and fossorial behaviour. The ranges of some species within these genera extend south into adjacent Namibia and Botswana. In arid habitats at the southern end of the Namib Desert, in the southern Dune Sea and adjacent Succulent Karoo biome these Angolan fossorial skink radiations are almost completely replaced by another suite of sepentiform skinks of the genera Scelotes, Typhlosaurus and Acontias. Only one species, Typhlacontias brevipes, of the Angolan radiation occurs in the northern parts of the southern Dune Sea. Increased knowledge of the history of aridification and dune movements of the Namib Desert may again give insight into these distributions.

That snake diversity in Angola is probably the most well known component of the reptile fauna is unsurprising. However, their distribution, particularly of forestadapted species in the northern and scarp forest isolates, remains poorly-known. The taxonomic status of these isolated forest populations calls for genetic studies on their phylogenetic relationships to confirm their conspecificity with northern populations. The diversity and composition of snake families in Angola reflects that of Africa, with relatively low diversity in primitive groups such as scolecophidians (Typhlopidae and Leptotyphlopidae) and haenophidians (Pythonidae). Again, in Angola as in southern Africa the venomous families Elapidae and Viperidae have slightly greater species diversity, but with more tropical representatives (e.g. the elapids Pseudohaje goldi, Naja annulata and N. melanoleuca, and viperids Causus lichtensteini, C. maculatus, Atheris squamigera and Bitis nasicornis). The dominant African snake family is the Lamprophiidae, of which the Atractaspididae is closely related and sometimes treated as a subfamily. The group appears to have originated in Africa and subsequently radiated into Arabia and Asia, and the subfamilies Lamprophiinae, Prosyminae and Psammophinae form important radiations in SubSaharan Africa. Lamprophids thus form the dominant component of the Angolan snake fauna (39 species), but includes only two endemic psammophines. As with elapids and viperids a number of Congo Basin species enter the northern forests, including some currently known from very few Angolan specimens, e.g. Lycodonomorphus subtaeniatus, Chamaelycus parkeri, Boaedon olivaceus, Bothrophthalmus lineatus, etc. Perhaps the greatest difference between South Africa and Angola is reflected in the greater diversity of colubrids (Colubridae) in Angola (28 vs 14 species). These include numerous tropical Congo Basin snakes that enter the northern and scarp forests, and of particular interest are the rare Congo Basin species Toxicodryas blandingii, T. pulverulenta, Rhamnophis aethiopissa, Philothamnus nitidus, Dasypelis palmarum, etc. The family is considered of Asian origin and to have entered and subsequently radiated in Africa. 


\section{Species Recorded from Angola but Poorly Known}

Some species are known from Angola from either a single or very few specimens and their presence and taxonomic status requires confirmation. This summary does not include wide ranging species that peripherally enter Angola, either from the Congo Basin (e.g. Pelusios gabonensis, Feylinia grandisquamis, Hypoptophis wilsoni, etc.), or from the southern Kalahari or Namib deserts (e.g. Rhoptropus afer, Pachydactylus rangei, P. vanzyli, Chamaeleo namaquensis, Amblyodipsas ventrimaculata, etc.).

Grass Lizard - Chamaesaura anguina oligopholis Laurent (1964). Described from Calonda, Lunda, but with no recent material. It may deserve specific status.

Angola Girdled Lizard - Cordylus angolensis (Bocage, 1895). Known only from the type description of a single male from Caconda, but a population that conforms to the species has recently been discovered (Vaz Pinto Unpublished Data).

Scaled Sandveld Lizard -Nucras scalaris Laurent 1964. Still known only from type series of four specimens from Alto Chicapa and Alto Chilo.

Dewitte's Five-toed Skink - Leptosiaphos dewittei (Loveridge, 1934). Recorded by Parker (1936, as Lygosoma dewittei) from Congulo. However, the only known Angolan specimen lacks the diagnostic compressed tail. The species occurs in the eastern Congo Basin, a considerable disjunction from Congulo.

African Shovel-nosed Snake - Scaphiophis albopunctatus Peters, 1870. Only once recorded from Angola (Laurent 1950, Muita River) in Guinea-Congo savannah habitat.

The only other know record is a juvenile specimen collected from Capaia, Lunde Norte (Branch and Conradie 2015).

Collared Snake-eater - Polemon collaris (Peters 1881). Recorded by Peters (1881, Cuango), Ferreira (1904, Golungo Alto) and Hellmich 1957a, b, Bella Vista, as Miodon gabonensis). Isolated populations of small fossorial snakes such as Polemon often include cryptic diversity (Portillo et al. 2018), and fresh material is required for taxonomic assessment.

Lined Water Snake - Lycodonomorphus (?) subtaeniatus Laurent 1954. Described from Keseki (DRC), with four paratypes from Dundo the only Angolan records. Greenbaum et al. (2015) transferred L. s. upembae to Boaedon. This is probably where L. subtaeniatus belongs but fresh material is required for genetic analysis.

Speckled Wolf Snake - Lycophidion meleagre Boulenger 1893. Described from Angola and known from Cabinda to Luanda, but Broadley (1996) also includes records from coastal Tanzania in the species' range, creating a biogeographic anomaly that requires genetic assessment.

Parker's Banded Snake - Chamaelycus parkeri (Angel, 1934). Parker's (1936) Congulo specimen (as Oophilositum parkeri) remains the only known Angolan material. Elsewhere the species is restricted to Kivu (DRC) and Congo Brazzaville, and confirmation of the specific status of the Congulo population is required. 
Angolan Coral Snake - Aspidelaps lubricus cowlesi Bogert 1940. Described from Munhino (101 km east of Moçamedes, via railroad), and known from Angola from the type and one additional specimen (Branch 2018). Considered widespread in northern Namibia, but genetic monophyly between Angolan and Nambian populations is required for confirmation.

Angolan Garter Snake - Elapsoidea semiannulata moebiusi Werner, 1897. Listed by Broadley (2006) from northern Angola, but with no specific localities given. All Bocage localities $(1866,1895,1897)$ were restricted to Bissau specimens. A southern subspecies is now treated as a valid species (E. boulengeri). The status of E. s. moebiusi requires a modern taxonomic assessment and also confirmation for Angola.

Angolan Dwarf Adder - Bitis heraldica (Bocage, 1889). Angola's most iconic snake for which no new material was collected for over 50 years has recently been rediscovered. It has a disjunct distribution in montane grasslands of the Angolan inland plateau, and the fresh material will allow its subgeneric relationships within Bitis to be assessed as well as its conservation status.

\section{Species Likely to Occur in Angola but Currently Unconfirmed}

A number of species are recorded in close proximity to the Angolan border and live in habitats contiguous with those in Angola, and are therefore likely to occur in the country. They include:

\section{Lizards}

Heenen's Dwarf Day Gecko - Lygodactylus heeneni De Witte, 1933. This small diurnal gecko was recorded from the Ikelenge Pedicle in northwest Zambia (Broadley 1991; Haagner et al. 2000) within $25 \mathrm{~km}$ of the Angolan border.

Long-tailed Worm Lizard - Dalophia longicauda (Werner, 1915). This fossorial species was described from northern Namibia and is known to extend through the Caprivi region to western Zimbabwe (Broadley et al. 1976; Gans 2005) and also to southwest Zambia (Pietersen et al. 2017). Populations occur to the east and west of the Okavango River and are expected to occur in southeast Angola.

Maurice's Worm Lizard - Monopeltis mauricei Parker, 1935. This fossorial species was described from central Botswana and is known to extend through the Kalahari to Katima Mulilo in the Caprivi region (Broadley et al. 1976; Gans 2005). Elevated to a full species by Broadley (2001).

West African Striped Lizard - Poromera fordii (Hallowell, 1857). An arboreal species recorded during a survey in the Bas-Congo region (Nagy et al. 2013) within $30 \mathrm{~km}$ of the Angolan border but currently unknown from Angola.

Fine-scaled forest lizard - Adolfus africanus (Boulenger, 1906). A terrestrial species recorded from the Ikelenge Pedicle in northwest Zambia (Broadley 1991), within $25 \mathrm{~km}$ of the Angolan border. 


\section{Snakes}

Western Thread Snake - Namibiana occidentalis (FitzSimons, 1962) occurs in extreme Kaokoveld (Broadley and Broadley 1999) but has not yet been recorded from southern Angola. The single record of the Damara Thread Snake (N. labialis Sternfeld, 1908) from southern Angola demonstrates that these small snakes can cross the Cunene River.

Leptotyphlops sp. An unidentified thread snake was recorded during a survey of the Bas-Congo region (Nagy et al. 2013). Based on its forest habitat it is unlikely to be referable to any known Angolan species.

Slender Quill-snouted Snake - Xenocalamus b. bicolor (Günther 1868). Although Broadley (1971) records no Angolan material, the species occurs in the Caprivi area and adjacent western Zambia, and it is usually associated with Kalahari sands. It is therefore likely to occur in southeast Angola

Bark Snake - Hemirhaggheris nototaenia (Günther, 1864). This dwarf arboreal snake is recorded from the western Caprivi and Okavango region, and extends eastwards through Zambia to East Africa. Earlier records from southwest Angola (Bocage, 1895) were later referred to H. viperina (Broadley and Hughes 2000). It is a secretive snake and may still be found in the miombo woodlands of southeast Angola.

Cunene Racer - Mopanveldophis zebrinus (Broadley and Schätti 2000). This enigmatic colubrid snake remains known from only a handful of specimens. The type locality is the Cunene River at Ruacana, western Owamboland, Namibia $\left(17^{\circ}\right.$ $25^{\prime} \mathrm{S}, 14^{\circ} 10^{\prime} \mathrm{E}$ ), and it appears restricted to the Mopaneveld of northern Namibia and can be expected to occur in similar habitat in southern Angola.

\section{Endemism in Angolan Reptiles}

Species that are fully endemic or near endemic to a country (i.e. those that have over $90 \%$ of known records included in that country), should be highlighted for national conservation monitoring as their protection depends completely on the national authorities. Only six species of snake are endemic to Angola, but no chelonians or crocodilians. Endemic snakes include two species of primitive thread snake, Namibiana latifrons and $N$. rostrata, that are the northern members of a small genus (five species) endemic to the western arid region of southern Africa (Adalsteinsson et al. 2009). Three rare snakes are also endemic to the high plateau region, including the psammophines Psammophis ansorgi and Psammophylax ocellatus (Branch et al. 2019), as well as the rare and iconic Bitis heraldica, which may be now of high conservation concern. During the Hamburg Expedition 10 specimens were collected from Bela Vista (Hellmich 1957a, b), but only one other specimen (Mount Moco) has been recorded in last 60 years (FM Gonçalves, photo 2010). Extensive clearing of natural habitat for agriculture, and increased fire risk in these montane grasslands may threaten the species. 
Lizards contain the greatest number of endemic and near-endemic Angolan reptiles, particularly among cordylids (two endemic, 50\%), lacertids (one near endemic, six endemic, 53.8\%), rupicolous geckos (eight endemic, 23.5\%), amphisbaenians (one near endemic, three endemic species; 36.4\%), and diverse skinks (one near endemic, six endemic, 16.3\%). Agama planiceps schacki is certainly a full species that is well-defined morphologically, but requires genetic assessment. It would also be endemic to Angola. None of these endemic lizards are currently considered of conservation concern. Only $12.7 \%$ of all Angolan reptiles are endemic as opposed to $41.2 \%$ of those in South Africa. This number increases to nearly $20.5 \%$ when only lizards are considered, but is still much less than the $54.9 \%$ of endemic lizards in South Africa (Table 13.3). However, the number of endemic species in the country has increased with the description of new Angolan taxa (e.g. Kolekanus plumicaudus, Pedioplanis haackei, P. huntleyi and Cordylus namakuiyus), and will increase further as new species in the genera Nucras, Heliobolus, Pedioplanis, Afroedura, Rhoptropus, Pachydactylus, Trachylepis and Boaedon discovered during recent surveys are described.

\section{Reptile Hotspots}

The existing global protected area network and conservation priorities are heavily biased towards amphibian, avian and mammal faunas (Roll et al. 2017). Reptiles, which represent a third of terrestrial vertebrate diversity, have been largely ignored, in part, because their diversity and distribution was not globally assessed until 2017. Both the global (Roll et al. 2017) and African (Lewin et al. 2016) assessments demonstrated that whilst the distribution patterns of species richness of all reptiles combined, as well as those of snakes, revealed similar patterns to those of the other three tetrapod classes, the patterns displayed by hotspots of total and endemic lizards and chelonian richness do not overlap significantly with those of other terrestrial tetrapods. A detailed analysis of reptile hotspots within Angola awaits fuller details of species diversity and distributions, both of which are still in their formative period. However, it is already evident that certain regions and their associated habitats and reptile faunas, particularly for endemic or near endemic species, present unique associations, some of which may be confirmed as regionally important reptile hotspots.

\section{Kaokoveld Centre of Endemism}

Lizard diversity in southern Africa, particularly in the western arid regions, is the highest in Africa, and the existence of similar habitat structure and diversity in southwest Angola indicates that this African lizard hotspot may also extend into Angola in association with arid and hyper-arid habitats. In association with desert 
habitats a number of characteristic Namib reptiles cross the Cunene River and just enter extreme southwest Angola, including: Gerrhosaurus skoogi, Pachydactylus rangei, P. vanzyli, Chamaeleo namaquensis, Meroles anchietae, M. reticulata, Trachylepis puncutula, and Bitis caudalis. Recent discoveries also suggest the existence of an endemic Angolan Namib reptile fauna, including the existing Angolan Namib endemics Pedioplanis benguellensis, Typhlacontias rudebecki, and T. punctatissimus bogerti, as well as a number newly described species in the region, e.g. Kolekanus plumicaudus (Haacke 2008), Pedioplanis huntleyi, P. haackei (Conradie et al. 2012a), and Cordylus namakuiyus (Stanley et al. 2016). Moreover, recent surveys in the region have revealed numerous examples of cryptic diversity in some lizard genera, where new species of Afroedura, Pachydactylus, Nucras, Pedioplanis endemic to the Angolan Namib region have been identified and await description.

At its northern and southern limits, the Namib Desert transforms into semi-arid, often succulent vegetation that may be loosely termed the 'Pro-Namib' region. In the south this forms the Succulent Karoo, a botanical hotspot of regional endemism and floral beauty (CEPF 2003). The Succulent Karoo has diverse and specialised reptile endemics (Branch 1994; Bauer and Branch 2003), and the region has been highlighted as a regional reptile hotspot, including numerous species of conservation concern (Branch 2014). As with the Succulent Karoo, the recognition of a unique reptile fauna in southwest Angola supports a corresponding northern 'ProNamib', in some ways analogous to the Succulent Karoo, and that has been identified as a distinctive phytogeographical region - the Kaokoveld Centre of Endemism, which extends as a narrow strip north of Namibe to Lucira and is characterised by a number of localised succulents (see Craven 2009 for fuller discussion).

\section{Angolan Escarpment}

Inland from the coastal arid herpetofauna is the Bié section (sensu Clark et al. 2011) of the Angolan Escarpment and adjacent high plateau. The southern African Great Escarpment (GE) forms a semi-continuous U-shaped mountain chain that runs for $5000 \mathrm{~km}$ from western Angola through Namibia and South Africa to the ZimbabweMozambique border. Clark et al. (2011) noted that the GE hosts more than half of southern Africa's centres of plant endemism and is a repository of palaeo- and neoendemics. It also has a rich endemic fauna and its fragmented sections serve as refugia and as episodic corridors for biological continuity. However, many sections of the Great Escarpment have been poorly studied, particularly in Angola where the Bié Escarpment summit and adjacent highlands is one of the most isolated sections of the Afromontane archipelago in Africa. With ca. 20 endemic bird species it forms the core of the Western Angola Endemic Bird Area. Other faunal groups have not been as extensively studied, but endemic reptiles associated with the Serra da Chela grasslands and wetlands include two endemic snakes (Psammophylax ocellatus and Psammophis ansorgi), the chameleon Chamaeleo anchietae, the serpentine skink Eumecia anchietae, the skink Trachylepis bayoni huilensis, the gecko Rhoptropus 
montanus, and the lacertid Ichnotropis bivittata pallida. A new reed frog, Hyperolius chelaensis was also recently discovered (Conradie et al. 2012b). In the adjacent highlands, including Mount Moco, at least two new species of the Afroedura bogerti complex have also been signalled (Branch et al. 2017).

\section{Northern Congo Forests}

The Congo Basin has numerous forest specialists, particularly snakes. Many of these are found in forests in Cabinda and along the northern border of Angola. These forests have only been incidentally surveyed, particularly the numerous important snake records listed in a series of papers based on the Museu do Dundo collections (Laurent 1950, 1954, 1964; Tys van den Audenaerde 1967). Among these collections are the only known Angolan records Gonionotophis brussauxi Letheobia praeocularis, Xenocalamus bicolour machadoi, Hypoptophis wilsoni katangae, Grayia tholloni, Philothamnus nitidus, Bothrophthalmus lineatus, Boaedon olivaceus, Lycodonomorphus subtaeniatus, Prosymna ambigua brevis and Causus lichtensteini. In addition, other Congo Basin reptiles only recorded from Dundo include the terrapin Pelusios gabonensis, the worm lizard Monopeltis vanderysti, and the skinks Lepidothyris hinkeli joei (as Mochlus fernandi, Laurent 1964) and Feylinia grandisquamis (as F. elegans, Laurent 1964). Parker (1936) presented the first survey of the central scarp forests of the Angolan Escarpment and recorded numerous Congo Basin snakes. For many species these remain their southern records, and they probably occur as disjunct, relictual populations. Some were subsequently recorded further north in forest habitats from Dundo or during the Hamburg Angola Expedition at Piri Dembos (see above). They include: Toxicodryas blandingii, T. pulverulenta, Atractaspis reticulata heterochilus, Bitis nasicornis, and Pseudohaje goldii. Others remain known only from Parkers' records: i.e. the skinks Panaspis breviceps, Leptosiaophis dewittei, and Trachylepis affinis; and the snakes Lycophidion ornatum, Chamaelycus parkeri (as Oophilositum parkeri) and Hormonotus modestus. The Congo Basin snake Rhamnophis aethiopissa is recorded in Angola only from Piri Dembos (Hellmich 1957a, b). The taxonomic status of all these isolates requires genetic confirmation as some may have undergone vicariant speciation. A phylogenetic assessment may give insight towards dating the separation of these forest isolates and understanding their biogeographic importance.

The forests of Cabinda form part of the Congo Basin and a number of reptiles occur there which have not been recorded in Angola south of the Congo River. Currently Cabinda remains the southern limit of the African Dwarf Crocodile (Osteolaemus tetraspis) and the Soft-shelled Terrapin (Cycloderma). The presence of two other reptiles recorded from Cabinda by Peters $(1876,1877)$, e.g. Owen's Horned Chameleon (Triceros oweni) and the skink Euprepes perrotetii (= Trachylepis perrotetii) are problematic. The latter is widespread in West Africa but not known even from Gabon. Peters (1877) recorded Euprepes perrotetii from 
Chinchoxo, Cabinda, and in a supplement to the same article noted a specimen from Pungo Andongo, upon which he considered it to form part of the fauna of Angola. However, no subsequent records of this distinctive species have been recorded from Angola. Although it is possible that these specimens were confused with large fire skinks (Lepidothrys sp.), Wagner et al. (2009) reviewed the genus and noted no misidentifications among the material they examined. It is more likely that Peters' specimens were simply accompanied by incorrect locality data. Forest chameleons are difficult to locate unless specifically targeted during faunal surveys, and Owen's Horned Chameleon is known from Gabon. No recent collections of both these species confirm their presence in Cabinda. Research underlying the proposed Mayombe Transfrontier Reserve (MTR) to protect forests in Cabinda and adjacent countries has concentrated on the large mammals, particular the Great Apes, and no detailed herpetological surveys have been undertaken. Recent surveys of the forest herpetofauna of the Serra do Pingano Ecosystem, Uíge Province (Ernst 2015) concentrated on amphibians but did record an number of interesting reptiles, particularly the arboreal lacertid Holaspis guentheri and water snake Grayia ornata, the former being the second record for the country (Laurent 1964) and the latter one of the few records for the country (Branch 2018). The northern tropical forests of Angola are threatened by massive timber extraction, and desperately need to be scientifically surveyed before their associated herpetofauna is lost.

\section{Future Directions for Reptile Research in Angola}

\section{The Continued Need for Further Field Surveys and Taxonomic Studies}

The conservation status and threats for African reptiles were reviewed by Tolley et al. (2016), who noted the large discrepancy between taxonomic sampling and documentation between many countries. They presented a scatter-plot of measured reptile species richness relative to log-transformed country area from African countries. This illustrated the great contrast between known reptile diversity in well surveyed countries such as South Africa, Kenya and Tanzania, with that of the majority of Africa. Angola is the seventh largest African country and has both habitat and topographic diversity. Together these features should generate rich biological diversity, but this is not reflected in our current knowledge of Angolan reptile diversity. Branch (2016) presented species accumulation curves documenting the growth in taxonomic knowledge of Angolan and southern African reptiles, noting that there has been no decline in the rate of new species discovery in the subcontinent during the last 150 years. This is in marked contrast to the relative stagnation of taxonomic discovery in Angola since the early part of the twentieth century (see Fig. 13.1 and Table 13.1 for comparison). As noted earlier, despite Angola and South Africa being of comparable size and habitat diversity there is a difference of over 150 species of 


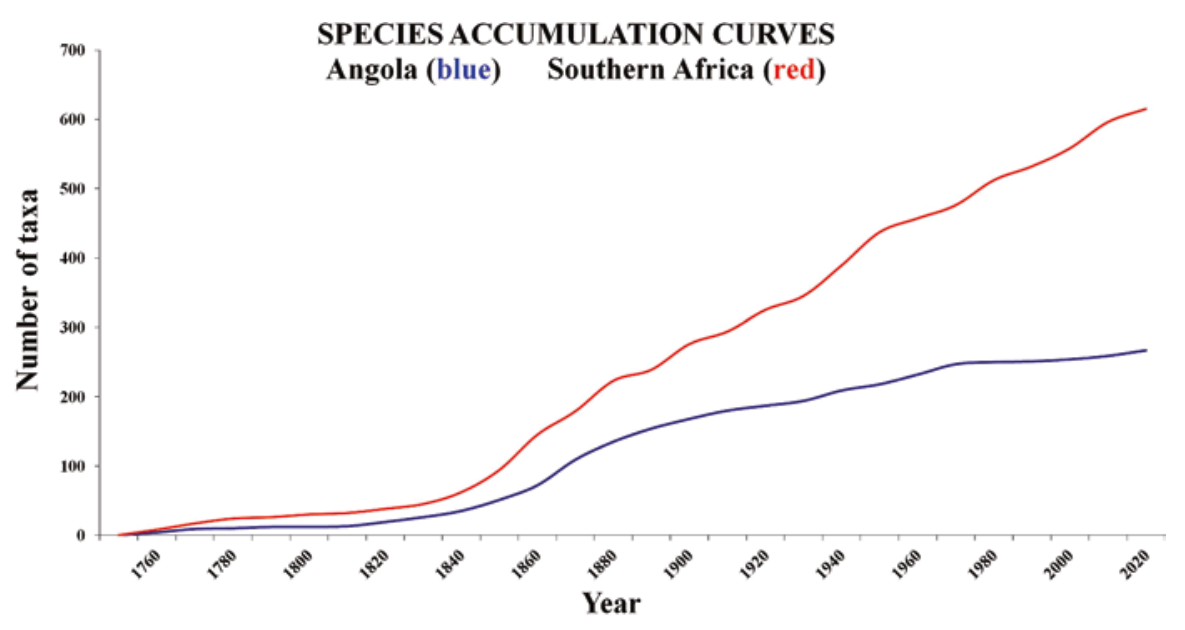

Fig. 13.1 Species accumulation curves for reptile discoveries in Angola (blue) and southern Africa (red) showing the relative stagnation of Angolan reptile species descriptions during the twentieth century. By the end of the nineteenth century $67.4 \%$ of Angolan reptiles had already been described, in contrast to less than half (47.8\%) of those in southern Africa

lizards between the two countries (Angola 132, South Africa 286). This contrast is even higher in terms of endemicity, where only 27 (20.5\%) of 132 Angolan lizards are endemic in contrast to $157(54.9 \%)$ of 286 South African lizards. It would appear that perhaps as many as 75+ new lizard species await discovery in Angola, and that many of these will be endemic. Branch (2014) noted that endemicity in South African lizards was particularly evident in rupicolous forms (many geckos, cordylids and skinks) associated with rocky outcrops. Rock exposures may form an archipelago of 'sky islands' on which isolation inhibits gene flow and thus leads to speciation. It is the lizard families containing large numbers of rupicolous species, i.e. Gekkonidae, Cordylidae and Scincidae, already show the greatest levels of endemicity among Angolan reptiles, and in which recent surveys have already identified numerous cryptic taxa (Stanley et al. 2016; Branch et al. 2017).

\section{Field Surveys of Potential Biodiversity 'Hotspots'}

Many African protected areas underperform in their stated conservation goals (Lindsey et al. 2014; Bowker et al. 2017). It is now generally accepted that modern national and internationally co-ordinated networks of protected area should be designed to cover important biodiversity hotspots and also protect habitats essential for the maintenance of ecosystem services such as water flow and quality, nutrient transfer, etc. (NPAES 2010). Such a revised Angolan network was proposed many 
years ago (Huntley 1974), and initial biodiversity surveys to gain insight into biodiversity in potential sites were undertaken (Huntley 2009; Huntley and Francisco 2015). Recent studies have shown that protected reserves designed to protect mammals, birds and amphibians are effective in protecting snakes, but fare badly in protecting African lizard diversity (Lewin et al. 2016; Roll et al. 2017). Future systematic biodiversity surveys should be directed to unique habitats and landforms in undersampled regions. Some of the interesting species recorded on recent field surveys are illustrated in Fig. 13.2.

\section{Biogeography of Angolan Reptiles}

Huntley (2019) in the introduction to this volume has presented a biogeographic outline, summarising various aspects of climate, geology and vegetation, etc., that characterise Angola. He noted the complexity of the Angolan landscape, where seven of the nine African biomes are represented in Angola as well as the second largest representation of ecoregion diversity in Africa. Monard (1937) and Hellmich (1957a, b) made preliminary attempts to assess biogeographic patterns among Angolan reptiles. However, they did little more than look for coarse habitat associations within the Ethiopian region. These attempts were constrained by lack of knowledge of the true reptile diversity in the region and, more importantly, by the ignorance of reptile distributions as large tracts of the country were still unexplored. Moreover, recent studies indicate that reptile distributions, particularly those of lizards, are more influenced by substrate specificity and isolation than by vegetation type (Bauer and Lamb 2005; Roll et al. 2017). Recent biogeographic studies lay greater emphasis on evolutionary relationships within the group studied, and explore correlations between genetic divergence (as a proxy for time) and known dates of major events in landscape evolution. This approach searches for historical barriers to, or corridors for migration and gene flow. These may be generated, for example, by climatic changes associated with Ice Age cycles and the resultant contraction and expansion of forest and savanna, changes in historic coastlines and/or island connectivity, as well as the development of an 'arid' corridor at an Ice Age maxima, etc. The biological consequences of nascent rifting on river capture and other hydrological consequences on palaeolakes and wetlands have also been explored (Cotterill and De Wit 2011). However, the application of such approaches requires more detailed knowledge of reptile distribution within Angola, as well as the availability of genetic material and adequate taxon sampling within a chosen group. These will allow historic climatic and landform events to be meaningful correlated with speciation and radiation within groups for testing phylogeographic hypotheses. Such studies depend on meaningful progress in the topics discussed earlier in this section. Advances in all these areas are required to fully understand and conserve the diversity and evolution of Angolan reptiles. 

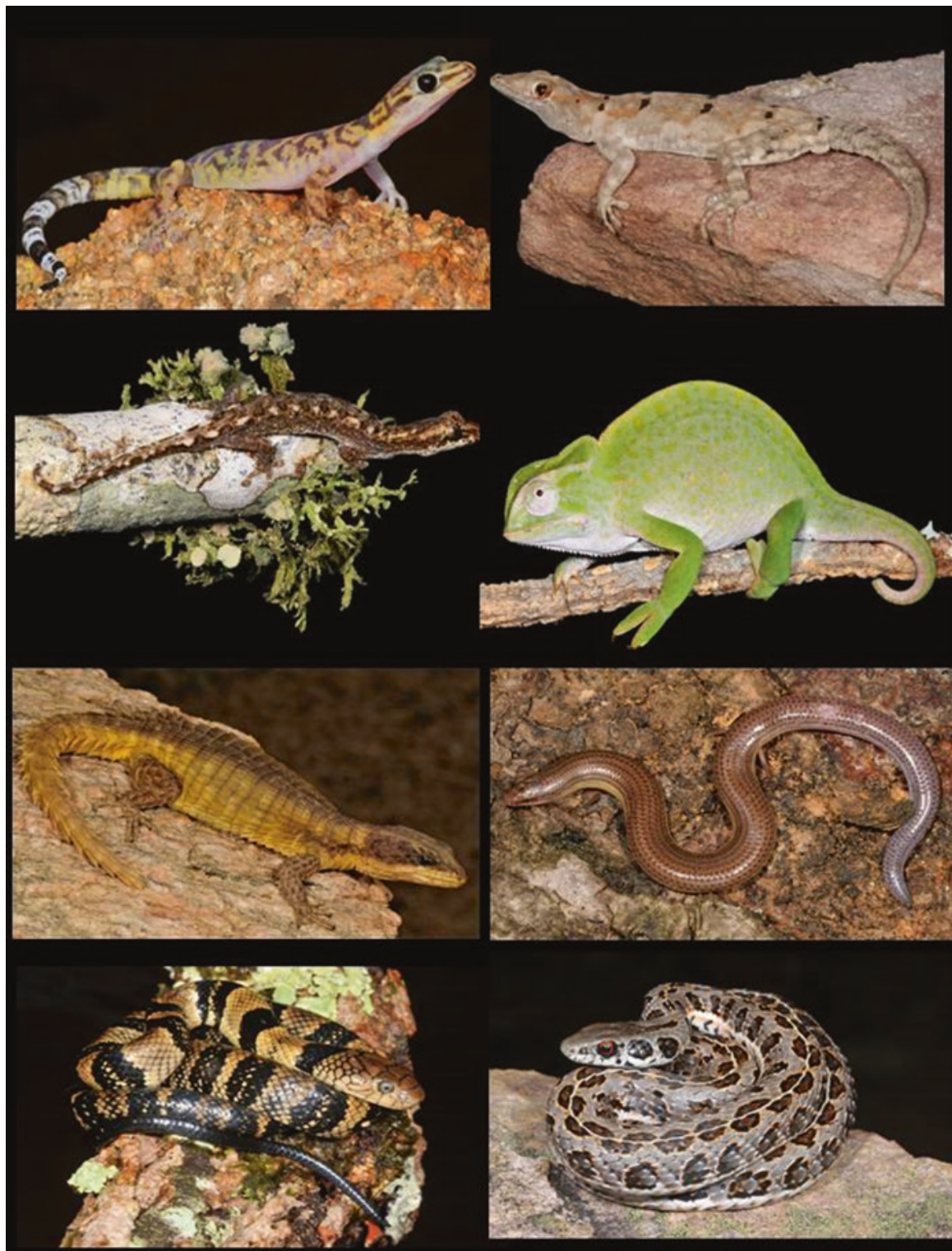

Fig. 13.2 Angolan reptiles. Top to bottom, left to right. Bogert's Flat Gecko (Afroedura cf. bogerti), Omahua Lodge, Namibe; Angolan Namib Day Gecko (Rhoptropus taeniostictus), Chapéu Armado, Namibe; Ansorge's Leaf-toed Gecko (Afrogecko ansorgii), Meve, Benguela; Anchieta's Chameleon (Chamaeleo anchietae), Humpata, Huíla; Kaokoveld Girdled Lizard (Cordylus namakuiyus), Rio Makonga, Namibe; Bayon's Legless Skink (Sepsina bayoni), Quiçama National Park, Luanda; Water Cobra (Naja annulata), Lagoa Carumbo, Lunde Norte; Angolan Skaapstekker (Psammophylax ocellatus), Humpata, Huíla 
Acknowledgements This review results from extensive collaboration by the authors and the Editor's of this volume during recent studies on the Angolan herpetofauna. It has been both synergistic and rewarding. Funding for research in Angola has been supported by: South Africa's National Research Foundation (2009-2017, WRB), National Geographic Society (Explorer Grant 2011, WRB; NGOWP and Wild Bird Trust 2015-2018, all authors), Fundação para a Ciência e Tecnologia (contract SFRH/PD/BD/140810/2018, NB). We are all particularly indebted to Fernandas Lages (ISCED), Brian Huntley (South Africa), and John Hilton (Wild Bird Trust) for their support with the documentation, logistics and permitting required for successful fieldwork in Angola.

\section{Appendices}

\section{Appendix 1}

Checklist of Angolan Chelonians and Crocodilians. C: Cabinda; Status: CITES (I, II $=$ Appendix 1 or 2 ), IUCN Conservation Status ${ }^{1}$. Species listed under ORDER/Family

\begin{tabular}{|c|c|c|c|c|}
\hline Common Name & Scientific Name & $\mathrm{C}$ & Bocage (1895) & Status \\
\hline \multicolumn{5}{|l|}{ Chelonia I Chelonidae } \\
\hline Loggerhead Sea Turtle & Caretta caretta (Linnaeus, 1758) & & $\begin{array}{l}\text { Thalassochelys } \\
\text { caretta }\end{array}$ & $\mathrm{I}, \mathrm{VU}$ \\
\hline Green Sea Turtle & Chelonia mydas (Linnaeus, 1758) & $\mathrm{Y}$ & Chelonia mydas & $\mathrm{I}, \mathrm{EN}$ \\
\hline Olive Ridley Sea Turtle & $\begin{array}{l}\text { Lepidochelys olivacea } \\
\text { (Eschscholtz, 1829) }\end{array}$ & $\mathrm{Y}$ & & $\mathrm{I}, \mathrm{VU}$ \\
\hline Hawksbill Sea Turtle & $\begin{array}{l}\text { Eretmochelys imbricata } \\
\text { (Linnaeus, 1766) }\end{array}$ & & & $\mathrm{I}, \mathrm{CR}$ \\
\hline \multicolumn{5}{|c|}{ Chelonia | Dermochelyidae } \\
\hline Leatherback Sea Turtle & $\begin{array}{l}\text { Dermochelys coriacea (Vandelli, } \\
1761 \text { ) }\end{array}$ & $\mathrm{Y}$ & & $\mathrm{I}, \mathrm{VU}$ \\
\hline \multicolumn{5}{|l|}{ Chelonia | Testudinidae } \\
\hline $\begin{array}{l}\text { Bell's Hinge-back } \\
\text { Tortoise }\end{array}$ & Kinixys belliana (Gray, 1831) & & Cinixys belliana & II \\
\hline $\begin{array}{l}\text { Forest Hinge-back } \\
\text { Tortoise }\end{array}$ & Kinixys erosa (Schweigger, 1812) & $\mathrm{Y}$ & Cinixys erosa & II, EN ${ }^{a}$ \\
\hline Leopard Tortoise & $\begin{array}{l}\text { Stigmochelys pardalis (Bell, } \\
\text { 1828) }\end{array}$ & & Testudo pardalis & II \\
\hline \multicolumn{5}{|c|}{ Chelonia I Pelomedusidae } \\
\hline Southern Marsh Terrapin & $\begin{array}{l}\text { Pelomedusa subrufa (Bonnaterre, } \\
\text { 1789) }\end{array}$ & & $\begin{array}{l}\text { Pelomedusa } \\
\text { galeata }\end{array}$ & \\
\hline $\begin{array}{l}\text { Okavango Hinged } \\
\text { Terrapin }\end{array}$ & $\begin{array}{l}\text { Pelusios bechuanicus } \\
\text { (FitzSimons, 1932) }\end{array}$ & & & \\
\hline Gabon Hinged Terrapin & $\begin{array}{l}\text { Pelusios gabonensis (Duméril, } \\
\text { 1856) }\end{array}$ & & & \\
\hline
\end{tabular}

(continued) 


\begin{tabular}{|c|c|c|c|c|}
\hline Common Name & Scientific Name & $\mathrm{C}$ & Bocage (1895) & Status \\
\hline Dwarf Hinged Terrapin & Pelusios nanus (Laurent, 1956) & & & \\
\hline Variable Hinged Terrapin & $\begin{array}{l}\text { Pelusios rhodesianus (Hewitt, } \\
\text { 1927) }\end{array}$ & & $\begin{array}{l}\text { Sternothaerus } \\
\text { sinuatus }\end{array}$ & \\
\hline Western Hinged Terrapin & $\begin{array}{l}\text { Pelusios castaneus (Schweigger, } \\
1812 \text { ) }\end{array}$ & $\mathrm{Y}$ & $\begin{array}{l}\text { Sternothaerus } \\
\text { Derbianus }\end{array}$ & \\
\hline \multicolumn{5}{|l|}{ Chelonia | Trionycidae } \\
\hline $\begin{array}{l}\text { Nile Soft-shelled } \\
\text { Terrapin }\end{array}$ & Trionyx triunguis (Forskàl, 1775) & $\mathrm{Y}$ & Trionyx triunguis & II, $\mathrm{VU}^{\mathrm{a}}$ \\
\hline $\begin{array}{l}\text { Aubrey's Flap-shelled } \\
\text { Terrapin }\end{array}$ & $\begin{array}{l}\text { Cycloderma aubryi (Dumeri, } \\
1856 \text { ) }\end{array}$ & $\mathrm{Y}$ & $\begin{array}{l}\text { Cycloderma } \\
\text { Aubryi }\end{array}$ & II, VU \\
\hline \multicolumn{5}{|c|}{ Crocodylia | Crocodylidae } \\
\hline Nile Crocodile & $\begin{array}{l}\text { Crocodylus niloticus (Laurenti, } \\
1768 \text { ) }\end{array}$ & & $\begin{array}{l}\text { Crocodilus } \\
\text { vulgaris }\end{array}$ & II \\
\hline $\begin{array}{l}\text { Central African } \\
\text { slender-snouted } \\
\text { Crocodile }\end{array}$ & $\begin{array}{l}\text { Mecistops leptorhynchus (Shirley } \\
\text { et al. 2018) }\end{array}$ & & $\begin{array}{l}\text { Crocodylus } \\
\text { cataphractus }\end{array}$ & $\mathrm{I}, \mathrm{DD}$ \\
\hline African Dwarf Crocodile & $\begin{array}{l}\text { Osteolaemus tetraspis (Cope, } \\
\text { 1861) }\end{array}$ & $\mathrm{Y}$ & $\begin{array}{l}\text { Ostelolaemus } \\
\text { tetraspis }\end{array}$ & I, EN \\
\hline
\end{tabular}

aTurtle Working Group 2017, Draft Red List

${ }^{b} I U C N$ Conservation Status categories. $C R$ Critically Endangered, EN Endangered, $V U$ Vulnerable, $D D$ Data Deficient

\section{Appendix 2}

Checklist of Angolan Lizards. C: Cabinda; Obs: Observations (E:endemic; NE: near-endemic). Species listed under ORDER|Family|Subfamily

\begin{tabular}{|c|c|c|c|c|}
\hline Common name & Scientific name & $\mathrm{C}$ & Bocage (1895) & Obs \\
\hline \multicolumn{5}{|l|}{ SAURIa I Agamidae } \\
\hline Angolan Tree Agama & $\begin{array}{l}\text { Acanthocercus } \\
\text { cyanocephalus (Falk, 1925) }\end{array}$ & & $\begin{array}{l}\text { Stellio angolensis Bocage } \\
1866 \text { is a nomen nudum } \\
\text { Stellio atricollis }\end{array}$ & \\
\hline Ground Agama & $\begin{array}{l}\text { Agama aculeata (Merrem, } \\
1820)\end{array}$ & & Agama armata & \\
\hline Anchieta's Agama & $\begin{array}{l}\text { Agama anchietae (Bocage, } \\
\text { 1896) }\end{array}$ & & & \\
\hline Congo Agama & $\begin{array}{l}\text { Agama congica (Peters, } \\
1877)\end{array}$ & $\mathrm{Y}$ & A. colonorum & \\
\hline Mucoso Agama & $\begin{array}{l}\text { Agama mucosoensis } \\
\text { (Hellmich, 1957) }\end{array}$ & & & $\mathrm{E}$ \\
\hline Namib Rock Agama & $\begin{array}{l}\text { Agama planiceps planiceps } \\
\text { (Peters, 1862) }\end{array}$ & & Agama planiceps & \\
\hline Schack's Rock Agama & $\begin{array}{l}\text { Agama p. schacki (Mertens, } \\
\text { 1938) }\end{array}$ & & & $\mathrm{E}$ \\
\hline
\end{tabular}




\begin{tabular}{|c|c|c|c|c|}
\hline Common name & Scientific name & $\mathrm{C}$ & Bocage (1895) & Obs \\
\hline \multicolumn{5}{|l|}{ SAURIA | Amphisbaenidae } \\
\hline $\begin{array}{l}\text { Angola Blunt-tailed } \\
\text { Worm Lizard }\end{array}$ & $\begin{array}{l}\text { Dalophia angolensis } \\
\text { (Gans, 1976) }\end{array}$ & & & $\mathrm{NE}$ \\
\hline $\begin{array}{l}\text { Ellenberger's Blunt-tailed } \\
\text { Worm Lizard }\end{array}$ & $\begin{array}{l}\text { Dalophia ellenbergeri } \\
\text { (Angel, 1920) }\end{array}$ & & & \\
\hline $\begin{array}{l}\text { Zambezi Blunt-tailed } \\
\text { Worm Lizard }\end{array}$ & $\begin{array}{l}\text { Dalophia pistillum } \\
\text { (Boettger, 1895) }\end{array}$ & & & \\
\hline $\begin{array}{l}\text { Welwitch's Blunt-tailed } \\
\text { Worm Lizard }\end{array}$ & $\begin{array}{l}\text { Dalophia welwitschii } \\
\text { (Gray, 1865) }\end{array}$ & & Monopeltis Welwitschii & E \\
\hline $\begin{array}{l}\text { Anchieta's Spade-snouted } \\
\text { Worm Lizard }\end{array}$ & $\begin{array}{l}\text { Monopeltis anchietae } \\
\text { (Bocage, } 1873 \text { ) }\end{array}$ & & Monopeltis anchietae & \\
\hline $\begin{array}{l}\text { Infuscate Spade-snouted } \\
\text { Worm Lizard }\end{array}$ & $\begin{array}{l}\text { Monopeltis infuscata } \\
\text { (Broadley, 1997) }\end{array}$ & & Monopeltis capensis & \\
\hline $\begin{array}{l}\text { Luanda Spade-snouted } \\
\text { Worm Lizard }\end{array}$ & $\begin{array}{l}\text { Monopeltis luandae (Gans, } \\
\text { 1976) }\end{array}$ & & & E \\
\hline $\begin{array}{l}\text { Confusing Spade-snouted } \\
\text { Worm Lizard }\end{array}$ & $\begin{array}{l}\text { Monopeltis perplexus } \\
\text { (Gans, 1976) }\end{array}$ & & & E \\
\hline $\begin{array}{l}\text { Vanderyst's Spade- } \\
\text { snouted Worm Lizard }\end{array}$ & $\begin{array}{l}\text { Monopeltis vanderysti (De } \\
\text { Witte, 1922) }\end{array}$ & & & \\
\hline $\begin{array}{l}\text { Balck Round-headed } \\
\text { Worm Lizard }\end{array}$ & $\begin{array}{l}\text { Zygaspis nigra (Broadley } \\
\text { and Gans, 1969) }\end{array}$ & & & \\
\hline $\begin{array}{l}\text { Kalahari Round-headed } \\
\text { Worm Lizard }\end{array}$ & $\begin{array}{l}\text { Zygaspis quadrifrons } \\
\text { (Peters, 1862) }\end{array}$ & & & \\
\hline \multicolumn{5}{|c|}{ SAURIA I Chamaeleonidae } \\
\hline Angolan Chameleon & $\begin{array}{l}\text { Chamaeleo anchietae } \\
\text { (Bocage, 1872) }\end{array}$ & & Chamaeleo anchietae & \\
\hline Flap-necked Chameleon & $\begin{array}{l}\text { Chamaeleo dilepis (Leach, } \\
\text { 1819) }\end{array}$ & $\mathrm{Y}$ & $\begin{array}{l}\text { Chamaeleon dilepis \& } C \text {. } \\
\text { quilensis }\end{array}$ & \\
\hline Etienne's Chameleon & $\begin{array}{l}\text { Chamaeleo gracilis } \\
\text { etiennei (Schmidt, 1919) }\end{array}$ & $\mathrm{Y}$ & Chamaeleon gracilis & \\
\hline Namaqua Chameleon & $\begin{array}{l}\text { Chamaeleo namaquensis } \\
\text { (Smith, 1831) }\end{array}$ & & $\begin{array}{l}\text { Chamaeleon } \\
\text { namaquensis }\end{array}$ & \\
\hline $\begin{array}{l}\text { Owen's Three-horned } \\
\text { Chameleon }\end{array}$ & $\begin{array}{l}\text { Trioceros oweni (Gray, } \\
\text { 1831) }\end{array}$ & & & \\
\hline \multicolumn{5}{|l|}{ SAURIA I Cordylidae } \\
\hline Northern Grass Lizard & $\begin{array}{l}\text { Chamaesaura miopropus } \\
\text { (Boulenger, 1895) }\end{array}$ & & Chamaesaura macrolepis & \\
\hline Angola Grass Lizard & $\begin{array}{l}\text { Chamaesaura anguina } \\
\text { oligopholis (Laurent, 1964) }\end{array}$ & & & $\mathrm{E}$ \\
\hline Angola Girdled Lizard & $\begin{array}{l}\text { Cordylus angolensis } \\
\text { (Bocage, 1895) }\end{array}$ & & Zonurus cordylus & $\mathrm{E}$ \\
\hline $\begin{array}{l}\text { Machado's Girdled } \\
\text { Lizard }\end{array}$ & $\begin{array}{l}\text { Cordylus machadoi } \\
\text { (Laurent, 1964) }\end{array}$ & & & \\
\hline $\begin{array}{l}\text { Kaokoveld Girdled } \\
\text { Lizard }\end{array}$ & $\begin{array}{l}\text { Cordylus namakuiyus } \\
\text { (Stanley et al, 2016) }\end{array}$ & & & $\mathrm{E}$ \\
\hline
\end{tabular}




\begin{tabular}{|c|c|c|c|c|}
\hline Common name & Scientific name & $\mathrm{C}$ & Bocage (1895) & Obs \\
\hline \multicolumn{5}{|l|}{ SAURIA | Gekkonidae } \\
\hline Bogert's Flat Gecko & $\begin{array}{l}\text { Afroedura bogerti } \\
\text { (Loveridge, 1944) }\end{array}$ & & & \\
\hline $\begin{array}{l}\text { Ansorge's Leaf-toed } \\
\text { Gecko }\end{array}$ & $\begin{array}{l}\text { Afrogecko ansorgii } \\
\text { (Boulenger, 1907) }\end{array}$ & & & $\mathrm{E}$ \\
\hline Button-scaled Gecko & $\begin{array}{l}\text { Chondrodactylus } \\
\text { fitzsimonsi (Loveridge, } \\
\text { 1947) }\end{array}$ & & & \\
\hline Pulitzer's Gecko & $\begin{array}{l}\text { Chondrodactylus pulitzerae } \\
\text { (Schmidt, 1933) }\end{array}$ & & $\begin{array}{l}\text { Pachydactylus Bibronii } \\
\text { (part) }\end{array}$ & \\
\hline Fisher's Gecko & $\begin{array}{l}\text { Chondrodactylus } \\
\text { laevigatus (Fischer, 1888) }\end{array}$ & & $\begin{array}{l}\text { Pachydactylus Bibronii } \\
\text { (part) }\end{array}$ & \\
\hline Pulitzer's Gecko & $\begin{array}{l}\text { Chondrodactylus pulitzerae } \\
\text { (Smith, 1933) }\end{array}$ & & & \\
\hline Bayão's House Gecko & $\begin{array}{l}\text { Hemidactylus bayonii } \\
\text { (Bocage, 1893) }\end{array}$ & & Hemidactylus bayonii & $\mathrm{E}$ \\
\hline Benguela House Gecko & $\begin{array}{l}\text { Hemidactylus benguellensis } \\
\text { (Bocage, 1893) }\end{array}$ & & $\begin{array}{l}\text { Hemidactylus } \\
\text { benguellensis }\end{array}$ & $\mathrm{E}$ \\
\hline Western House Gecko & $\begin{array}{l}\text { Hemidactylus brooki } \\
\text { angulatus (Hallowell 1852) }\end{array}$ & & & \\
\hline $\begin{array}{l}\text { Long-headed House } \\
\text { Gecko }\end{array}$ & $\begin{array}{l}\text { Hemidactylus } \\
\text { longicephalus (Bocage, } \\
1873 \text { ) }\end{array}$ & & Hemidactylus bocagii & \\
\hline Tropical House Gecko & $\begin{array}{l}\text { Hemidactylus mabouia } \\
\text { (Moreau De Jonnès, 1818) }\end{array}$ & $\mathrm{Y}$ & $\begin{array}{l}\text { Hemidactylus mabouia \& } \\
\text { H. benguellensis }\end{array}$ & \\
\hline Forest House Gecko & $\begin{array}{l}\text { Hemidactylus murecius } \\
\text { (Peters, 1870) }\end{array}$ & & Hemidactylus murecius & \\
\hline Plume-tailed Geco & $\begin{array}{l}\text { Kolekanos plumicaudus } \\
\text { (Haacke, 2008) }\end{array}$ & & & $\mathrm{E}$ \\
\hline $\begin{array}{l}\text { Angola Dwarf Day } \\
\text { Gecko }\end{array}$ & $\begin{array}{l}\text { Lygodactylus angolensis } \\
\text { (Bocage, 1896) }\end{array}$ & & & \\
\hline $\begin{array}{l}\text { Bradfield's Dwarf Day } \\
\text { Gecko }\end{array}$ & $\begin{array}{l}\text { Lygodactylus bradfieldi } \\
\text { (Hewitt, 1932) }\end{array}$ & & & \\
\hline Cape Dwarf Day Gecko & $\begin{array}{l}\text { Lygodactylus capensis } \\
\text { (Smith, 1849) }\end{array}$ & & Lygodacylus capensis & \\
\hline Hewitt's Punctate Gecko & $\begin{array}{l}\text { Pachydactylus amoenoides } \\
\text { (Hewitt, 1935) }\end{array}$ & & Pachydactylus ocellatus & \\
\hline Angola Thick-toed Gecko & $\begin{array}{l}\text { Pachydactylus angolensis } \\
\text { (Loveridge, 1944) }\end{array}$ & & & $\mathrm{E}$ \\
\hline Caricul Thick-toed Gecko & $\begin{array}{l}\text { Pachydactylus caraculicus } \\
\text { (FitzSimons, 1959) }\end{array}$ & & & \\
\hline $\begin{array}{l}\text { Kaokoveld Thick-toed } \\
\text { Gecko }\end{array}$ & $\begin{array}{l}\text { Pachydactylus cf. } \\
\text { oreophilus (McLachlan and } \\
\text { Spence, 1976) }\end{array}$ & & & \\
\hline
\end{tabular}




\begin{tabular}{|c|c|c|c|c|}
\hline Common name & Scientific name & $\mathrm{C}$ & Bocage (1895) & Obs \\
\hline $\begin{array}{l}\text { Punctate Thick-toed } \\
\text { Gecko }\end{array}$ & $\begin{array}{l}\text { Pachydactylus punctatus } \\
\text { (Peters, 1854) }\end{array}$ & & & \\
\hline Web-footed Gecko & $\begin{array}{l}\text { Pachydactylus rangei } \\
\text { (Andersson, 1908) }\end{array}$ & & & \\
\hline $\begin{array}{l}\text { Scherz's Thick-toed } \\
\text { Gecko }\end{array}$ & $\begin{array}{l}\text { Pachydactylus scherzi } \\
\text { (Mertens, 1954) }\end{array}$ & & & \\
\hline $\begin{array}{l}\text { Rough-scaled Thick-toed } \\
\text { Gecko }\end{array}$ & $\begin{array}{l}\text { Pachydactylus cf. rugosus } \\
\text { (Smith, 1849) }\end{array}$ & & & NR \\
\hline $\begin{array}{l}\text { Large-scaled Thick-toed } \\
\text { Gecko }\end{array}$ & $\begin{array}{l}\text { Pachydactylus scutatus } \\
\text { (Hewitt, 1927) }\end{array}$ & & & \\
\hline Kalahari Ground Gecko & $\begin{array}{l}\text { Pachydactylus wahlbergii } \\
\text { (Peters, 1869) }\end{array}$ & & & \\
\hline $\begin{array}{l}\text { Van Zyl's Web-footed } \\
\text { Gecko }\end{array}$ & $\begin{array}{l}\text { Pachydactylus vanzyli } \\
\text { (Steyn and Haacke, 1966) }\end{array}$ & & & \\
\hline $\begin{array}{l}\text { Common Namib Day } \\
\text { Gecko }\end{array}$ & $\begin{array}{l}\text { Rhoptropus afer (Peters, } \\
\text { 1869) }\end{array}$ & & & \\
\hline $\begin{array}{l}\text { Barnard's Namib Day } \\
\text { Gecko }\end{array}$ & $\begin{array}{l}\text { Rhoptropus barnardi } \\
\text { (Hewitt, 1926) }\end{array}$ & & Rhoptropus afer? & \\
\hline $\begin{array}{l}\text { Benguella Namib Day } \\
\text { Gecko }\end{array}$ & $\begin{array}{l}\text { Rhoptropus benguellensis } \\
\text { (Mertens 1938) }\end{array}$ & & & E \\
\hline $\begin{array}{l}\text { Two-pored Namib Day } \\
\text { Gecko }\end{array}$ & $\begin{array}{l}\text { Rhoptropus biporosus } \\
\text { (FitzSimons, 1957) }\end{array}$ & & & \\
\hline $\begin{array}{l}\text { Boulton's Namib Day } \\
\text { Gecko }\end{array}$ & $\begin{array}{l}\text { Rhoptropus boultoni } \\
\text { (Schmidt, 1933) }\end{array}$ & & & \\
\hline $\begin{array}{l}\text { Montane Namib Day } \\
\text { Gecko }\end{array}$ & $\begin{array}{l}\text { Rhoptropus montanus } \\
\text { (Laurent, 1964) }\end{array}$ & & & E \\
\hline $\begin{array}{l}\text { Angolan Namib Day } \\
\text { Gecko }\end{array}$ & $\begin{array}{l}\text { Rhoptropus taeniostictus } \\
\text { (Laurent, 1964) }\end{array}$ & & & E \\
\hline
\end{tabular}

SAURIA I Gerrhosauridae

\begin{tabular}{|c|c|c|c|}
\hline Dwarf Plated Lizard & $\begin{array}{l}\text { Cordylosaurus } \\
\text { subtessellatus (Smith, } \\
1844 \text { ) }\end{array}$ & & Cordylosaurus trivittatus \\
\hline Kalahari Plated Lizard & $\begin{array}{l}\text { Gerrhosaurus auritus } \\
\text { (Boettger, 1887) }\end{array}$ & & \\
\hline Laurent's Plated Lizard & $\begin{array}{l}\text { Gerrhosaurus bulsi } \\
\text { (Laurent, 1954) }\end{array}$ & & \\
\hline Keeled Plated Lizard & $\begin{array}{l}\text { Gerrhosaurus multilineatus } \\
\text { (Bocage, 1866) }\end{array}$ & & \\
\hline Black-lined Plated Lizard & $\begin{array}{l}\text { Gerrhosaurus nigrolineatus } \\
\text { (Hallowell, 1857) }\end{array}$ & $\mathrm{Y}$ & $\begin{array}{l}\text { Gerrhosaurus } \\
\text { nigrolineatus }\end{array}$ \\
\hline Desert Plated Lizard & $\begin{array}{l}\text { Gerrhosaurus skoogi } \\
\text { (Andersson, 1916) }\end{array}$ & & \\
\hline $\begin{array}{l}\text { Western Giant Plated } \\
\text { Lizard }\end{array}$ & $\begin{array}{l}\text { Matobosaurus maltzahni } \\
\text { (De Grys, 1938) }\end{array}$ & & Gerrhosaurus validus \\
\hline $\begin{array}{l}\text { Ellenberger's Snake } \\
\text { Lizard }\end{array}$ & $\begin{array}{l}\text { Tetradactylus ellenbergeri } \\
\text { (Angel, 1922) }\end{array}$ & & Caitia africana Gray \\
\hline
\end{tabular}




\begin{tabular}{|c|c|c|c|c|}
\hline Common name & Scientific name & $\mathrm{C}$ & Bocage (1895) & Obs \\
\hline \multicolumn{5}{|l|}{ SAURIA I Lacertidae } \\
\hline Bushveld Lizard & \begin{tabular}{|l} 
Heliobolus lugubris \\
(Smith, 1838)
\end{tabular} & & Eremias lugubris & \\
\hline $\begin{array}{l}\text { Northern Blue-tailed Tree } \\
\text { Lizard }\end{array}$ & $\begin{array}{l}\text { Holaspis guentheri (Gray, } \\
1863 \text { ) }\end{array}$ & & & \\
\hline $\begin{array}{l}\text { Western Rough-scaled } \\
\text { Lizard }\end{array}$ & $\begin{array}{l}\text { Ichnotropis b. bivittata } \\
\text { (Bocage, 1866) }\end{array}$ & & Ichnotropis capensis & \\
\hline Pale Rough-scaled Lizard & $\begin{array}{l}\text { Ichnotropis b. pallida } \\
\text { (Laurent, 1964) }\end{array}$ & & & $\mathrm{E}$ \\
\hline $\begin{array}{l}\text { Cape Rough-scaled } \\
\text { Lizard }\end{array}$ & $\begin{array}{l}\text { Ichnotropis c. capensis } \\
\text { (Smith, 1838) }\end{array}$ & & & \\
\hline $\begin{array}{l}\text { Overlaete's Rough-scaled } \\
\text { Lizard }\end{array}$ & $\begin{array}{l}\text { Ichnotropis c. overlaeti } \\
\text { (Witte and Laurent 1942) }\end{array}$ & & & \\
\hline $\begin{array}{l}\text { Small-scaled Rough- } \\
\text { scaled Lizard }\end{array}$ & $\begin{array}{l}\text { Ichnotropis microlepidota } \\
\text { (Marx, 1956) }\end{array}$ & & & $\mathrm{E}$ \\
\hline Shovel-snouted Lizard & $\begin{array}{l}\text { Meroles anchietae } \\
\text { (Bocage, } 1867 \text { ) }\end{array}$ & & Pachyrhynchus Anchietae & \\
\hline Reticulate Desert Lizard & $\begin{array}{l}\text { Meroles reticulatus } \\
\text { (Bocage, 1867) }\end{array}$ & & Scaptira reticulata & \\
\hline $\begin{array}{l}\text { Rough-scaled Desert } \\
\text { Lizard }\end{array}$ & $\begin{array}{l}\text { Meroles squamulosus } \\
\text { (Peters, 1854) }\end{array}$ & & & \\
\hline $\begin{array}{l}\text { Laurent's Sandveld } \\
\text { Lizard }\end{array}$ & $\begin{array}{l}\text { Nucras scalaris (Laurent, } \\
\text { 1964) }\end{array}$ & & & $\mathrm{E}$ \\
\hline Western Sandveld Lizard & $\begin{array}{l}\text { Nucras aff. tesselata } \\
\text { (Smith, 1838) }\end{array}$ & & & $\mathrm{NE}$ \\
\hline Benguella Sand Lizard & $\begin{array}{l}\text { Pedioplanis benguellensis } \\
\text { (Bocage, 1867) }\end{array}$ & & Eremias namaquensis & $\mathrm{E}$ \\
\hline Haacke's Sand Lizard & $\begin{array}{l}\text { Pedioplanis haackei } \\
\text { Conradie et al. } 2012\end{array}$ & & & $\mathrm{E}$ \\
\hline Huntley's Sand Lizard & $\begin{array}{l}\text { Pedioplanis huntleyi } \\
\text { (Conradie et al. 2012) }\end{array}$ & & & $\mathrm{E}$ \\
\hline \multicolumn{5}{|c|}{ SAURIA | Scincidae | Acontinae } \\
\hline Japp's Burrowing Skink & $\begin{array}{l}\text { Acontias jappi (Broadley, } \\
\text { 1968) }\end{array}$ & & & \\
\hline $\begin{array}{l}\text { Kalahari Burrowing } \\
\text { Skink }\end{array}$ & $\begin{array}{l}\text { Acontias kgalagadi } \\
\text { kgalagadi (Lamb et al., } \\
\text { 2010) }\end{array}$ & & & \\
\hline Western Burrowing Skink & $\begin{array}{l}\text { Acontias occidentalis } \\
\text { (FitzSimons, 1941) }\end{array}$ & & & \\
\hline \multicolumn{5}{|c|}{ SAURIA I Scincidae I Eugongylinae } \\
\hline $\begin{array}{l}\text { Shorted-headed } \\
\text { Snake-eyed Skink }\end{array}$ & $\begin{array}{l}\text { Panaspis breviceps (Peters, } \\
\text { 1873) }\end{array}$ & & & \\
\hline $\begin{array}{l}\text { Cabinda Snake-eyed } \\
\text { Skink }\end{array}$ & $\begin{array}{l}\text { Panaspis cabindae } \\
\text { (Bocage, } 1866 \text { ) }\end{array}$ & $\mathrm{Y}$ & Ablepharus cabindae & \\
\hline $\begin{array}{l}\text { Speckle-lipped Snake- } \\
\text { eyed Skink }\end{array}$ & $\begin{array}{l}\text { Panaspis maculicollis } \\
\text { (Jacobsen and Broadley, } \\
\text { 2000) }\end{array}$ & & & \\
\hline
\end{tabular}




\begin{tabular}{l|l|l|l|l}
\hline Common name & Scientific name & C & Bocage (1895) & Obs \\
\hline $\begin{array}{l}\text { Angolan Snake-eyed } \\
\text { Skink }\end{array}$ & $\begin{array}{l}\text { Panaspis aff. wahlbergii } \\
\text { complex }\end{array}$ & & Ablepharus wahlbergii & \\
\hline $\begin{array}{l}\text { De Witte's Leaf-litter } \\
\text { Skink }\end{array}$ & $\begin{array}{l}\text { Leptosiaphos dewittei } \\
\text { (Loveridge, 1934) }\end{array}$ & & & \\
\hline SAURIA I Scincidae I Lygosominae & & & \\
\hline Hinkel's Red-sided Skink & $\begin{array}{l}\text { Lepidothyris hinkeli } \\
\text { (Wagner et al., 2009) }\end{array}$ & & & \\
\hline $\begin{array}{l}\text { Sundevall's Writhing } \\
\text { Skink }\end{array}$ & $\begin{array}{l}\text { Mochlus sundevalli (Smith, } \\
\text { 1849) }\end{array}$ & & Lygosoma Sundevallii & \\
\hline S & & & & \\
\hline
\end{tabular}

SAURIA I Scincidae I Mabuyinae

\begin{tabular}{|c|c|c|c|c|}
\hline Anchieta's Snake Skink & $\begin{array}{l}\text { Eumecia anchietae } \\
\text { anchietae (Bocage, 1870) }\end{array}$ & & Lygosoma Anchietae & \\
\hline $\begin{array}{l}\text { Lunda Western Snake } \\
\text { Skink }\end{array}$ & $\begin{array}{l}\text { Eumecia a. major (Laurent, } \\
\text { 1964) }\end{array}$ & & & E \\
\hline Iven's Water Skink & $\begin{array}{l}\text { Lubuya ivensii (Bocage, } \\
\text { 1879) }\end{array}$ & & Lygosoma Ivensii & \\
\hline Wedge Snouted Skink & $\begin{array}{l}\text { Trachylepis acutilabris } \\
\text { (Peters, 1862) }\end{array}$ & $\mathrm{Y}$ & Mabuia acutilabris & \\
\hline Senegal Skink & $\begin{array}{l}\text { Trachylepis affinis (Gray, } \\
\text { 1838) }\end{array}$ & $\mathrm{Y}$ & $\begin{array}{l}\text { Mabuia Raddonii (not in } \\
\text { Angola) }\end{array}$ & \\
\hline Monard's Skink & $\begin{array}{l}\text { Trachylepis monardi } \\
\text { (Marques et al. 2018) }\end{array}$ & & & $\mathrm{E}$ \\
\hline Bayão’s Skink & $\begin{array}{l}\text { Trachylepis b. bayoni } \\
\text { (Bocage, 1872) }\end{array}$ & & Mabuia Bayonii & \\
\hline Huila Skink & $\begin{array}{l}\text { Trachylepis b. huilensis } \\
\text { (Laurent, 1964) }\end{array}$ & & & $\mathrm{E}$ \\
\hline Ovambo Stree Skink & $\begin{array}{l}\text { Trachylepis binotata } \\
\text { (Bocage, } 1867 \text { ) }\end{array}$ & & Mabuia bionotata & \\
\hline Bocage's Skink & $\begin{array}{l}\text { Trachylepis bocagii } \\
\text { (Boulenger, 1887) }\end{array}$ & & Mabuia Petersi & \\
\hline Chimba Skink & $\begin{array}{l}\text { Trachylepis chimbana } \\
\text { (Boulenger, 1887) }\end{array}$ & & Mabuia chimbana & \\
\hline Damara Skink & $\begin{array}{l}\text { Trachylepis damarana } \\
\text { (Peters, 1870) }\end{array}$ & & Mabuia varia (part) & \\
\hline Hoesch's Skink & $\begin{array}{l}\text { Trachylepis hoeschi } \\
\text { (Mertens, 1954) }\end{array}$ & & & \\
\hline Bronze Rock Skink & $\begin{array}{l}\text { Trachylepis cf. } \\
\text { lacertiformis (Peters, 1854) }\end{array}$ & & & \\
\hline $\begin{array}{l}\text { Angolan Blue-tailed } \\
\text { Skink }\end{array}$ & $\begin{array}{l}\text { Trachylepis laevis } \\
\text { (Boulenger, 1907) }\end{array}$ & & & \\
\hline Speckled-lipped Skink & $\begin{array}{l}\text { Trachylepis maculilabris } \\
\text { (Gray, 1845) }\end{array}$ & $\mathrm{Y}$ & Mabuia maculilabris & \\
\hline Grass Skink & $\begin{array}{l}\text { Trachylepis cf. megalura } \\
\text { (Peters, 1878) }\end{array}$ & & & \\
\hline $\begin{array}{l}\text { Western Three Striped } \\
\text { Skink }\end{array}$ & $\begin{array}{l}\text { Trachylepis occidentalis } \\
\text { (Peters, 1867) }\end{array}$ & & Mabuia occidentalis & \\
\hline
\end{tabular}




\begin{tabular}{|c|c|c|c|c|}
\hline Common name & Scientific name & $\mathrm{C}$ & Bocage (1895) & Obs \\
\hline Speckled Skink & $\begin{array}{l}\text { Trachylepis punctulata } \\
\text { (Bocage, 1872) }\end{array}$ & & Mabuia punctulata & \\
\hline Kalahari Tree Skink & $\begin{array}{l}\text { Trachylepis spilogaster } \\
\text { (Peters, 1882) }\end{array}$ & & & \\
\hline Striped Skink & $\begin{array}{l}\text { Trachylepis striata (Peters, } \\
\text { 1844) }\end{array}$ & & Mabuia striata & \\
\hline Ansorge's Rock Skink & $\begin{array}{l}\text { Trachylepis sulcata } \\
\text { ansorgii (Boulenger, 1907) }\end{array}$ & & Mabuia sulcata & \\
\hline Angolan Variable Skink & $\begin{array}{l}\text { Trachylepis cf. } \\
\text { albopunctata (Bocage, } \\
\text { 1867) }\end{array}$ & & Mabuia varia (part) & \\
\hline Wahlberg's Skink & $\begin{array}{l}\text { Trachylepis wahlbergi } \\
\text { (Peters, 1869) }\end{array}$ & & & \\
\hline \multicolumn{5}{|c|}{ SAURIA I Scincidae I Scincinae } \\
\hline $\begin{array}{l}\text { Curror's giant burrowing } \\
\text { Skink }\end{array}$ & $\begin{array}{l}\text { Feylinia currori (Gray, } \\
1845 \text { ) }\end{array}$ & $\mathrm{Y}$ & Feylinia Currori & \\
\hline $\begin{array}{l}\text { Large-scaled burrowing } \\
\text { Skink }\end{array}$ & $\begin{array}{l}\text { Feylinia grandisquamis } \\
\text { (Müller, 1910) }\end{array}$ & & & \\
\hline Western Limbless Skink & $\begin{array}{l}\text { Melanoseps occidentalis } \\
\text { (Peters, 1877) }\end{array}$ & & & \\
\hline Angolan burrowing Skink & $\begin{array}{l}\text { Sepsina angolensis } \\
\text { (Bocage, } 1866 \text { ) }\end{array}$ & & Sepsina angolensis & \\
\hline Bayão’s Burrowing Skink & $\begin{array}{l}\text { Sepsina bayoni (Bocage, } \\
1866 \text { ) }\end{array}$ & $\mathrm{Y}$ & Sepsina Bayonii & $\mathrm{NE}$ \\
\hline Cope's Burrowing Skink & $\begin{array}{l}\text { Sepsina copei (Bocage, } \\
1873 \text { ) }\end{array}$ & & Sepsina Copei & $\mathrm{E}$ \\
\hline $\begin{array}{l}\text { Johnson's Western } \\
\text { Burrowing Skink }\end{array}$ & $\begin{array}{l}\text { Typhlacontias johnsonii } \\
\text { (Andersson, 1916) }\end{array}$ & & & \\
\hline $\begin{array}{l}\text { Speckled Western } \\
\text { Burrowing Skink }\end{array}$ & $\begin{array}{l}\text { Typhlacontias } p \text {. } \\
\text { punctatissimus (Bocage, } \\
1873 \text { ) }\end{array}$ & & $\begin{array}{l}\text { Typhlacontias } \\
\text { punctatissimus }\end{array}$ & \\
\hline $\begin{array}{l}\text { Bogert's Western } \\
\text { Burrowing Skink }\end{array}$ & $\begin{array}{l}\text { Typhlacontias } p \text {. bogerti } \\
\text { (Laurent, 1964) }\end{array}$ & & & $\mathrm{E}$ \\
\hline $\begin{array}{l}\text { Rohan's Western } \\
\text { Burrowing Skink }\end{array}$ & $\begin{array}{l}\text { Typhlacontias rohani } \\
\text { (Angel, 1923) }\end{array}$ & & & \\
\hline $\begin{array}{l}\text { Rudebeck's Western } \\
\text { Burrowing Skink }\end{array}$ & $\begin{array}{l}\text { Typhlacontias rudebecki } \\
\text { (Haacke, 1997) }\end{array}$ & & & $\mathrm{E}$ \\
\hline \multicolumn{5}{|l|}{ SAURIA / Varanidae } \\
\hline Savanna Monitor & \begin{tabular}{|l|} 
Varanus albigularis \\
angolensis (Schmidt, 1933)
\end{tabular} & & Varanus albigularis & \\
\hline Water Monitor & \begin{tabular}{|l} 
Varanus niloticus \\
(Linneaus, 1766)
\end{tabular} & $\mathrm{Y}$ & Varanus niloticus & \\
\hline
\end{tabular}




\section{Appendix 3}

Checklist of Angolan Snakes. C: Cabinda; Obs: Observations (E:endemic; NE: near-endemic; NR: new record for Angola; RC: requires confirmation). Species listed under OrDER | Family | Subfamily

\begin{tabular}{|c|c|c|c|c|}
\hline Common name & Scientific name & $\mathrm{C}$ & Bocage (1895) & Obs \\
\hline \multicolumn{5}{|c|}{ SCOLECOPHIDIA | Leptotyphlopidae } \\
\hline Shaba Thread Snake & $\begin{array}{l}\text { Leptotyphlops kafubi } \\
\text { (Boulenger, 1919) }\end{array}$ & & & \\
\hline Peter's Thread Snake & $\begin{array}{l}\text { Leptotyphlops scutifrons } \\
\text { (Peters, 1854) }\end{array}$ & & \begin{tabular}{|l} 
Stenosoma \\
scutifrons
\end{tabular} & \\
\hline Damara Thread Snake & $\begin{array}{l}\text { Namibiana labialis (Sternfeld, } \\
\text { 1908) }\end{array}$ & & & \\
\hline Benguela Thread Snake & $\begin{array}{l}\text { Namibiana latifrons (Sternfeld, } \\
\text { 1908) }\end{array}$ & & & E \\
\hline $\begin{array}{l}\text { Angolan Beaked Thread } \\
\text { Snake }\end{array}$ & $\begin{array}{l}\text { Namibiana rostrata (Bocage, } \\
1886 \text { ) }\end{array}$ & & $\begin{array}{l}\text { Stenosoma } \\
\text { rostratum }\end{array}$ & E \\
\hline \multicolumn{5}{|c|}{ SCOLECOPHIDIA I Typhlopidae } \\
\hline Angolan Blind Snake & $\begin{array}{l}\text { Afrotyphlops angolensis } \\
\text { (Bocage, 1866) }\end{array}$ & & Typhlops punctatus & \\
\hline $\begin{array}{l}\text { Angolan Giant Blind } \\
\text { Snake }\end{array}$ & $\begin{array}{l}\text { Afrotyphlops anomalus } \\
\text { (Bocage, 1873) }\end{array}$ & & $\begin{array}{l}\text { Typhlops anomalus } \\
\text { \& T. anchietae }\end{array}$ & \\
\hline Blotched Blian Snake & $\begin{array}{l}\text { Afrotyphlops congestus } \\
\text { (Duméril and Bibron, 1844) }\end{array}$ & Y & & \\
\hline Lined Blind Snake & $\begin{array}{l}\text { Afrotyphlops lineolatus (Jan, } \\
\text { 1864) }\end{array}$ & $\mathrm{Y}$ & $\begin{array}{l}\text { Typhlops punctatus } \\
\text { var. lineolatus \& } \\
\text { Typhlops boulengeri }\end{array}$ & \\
\hline Schmidt's Blind Snake & $\begin{array}{l}\text { Afrotyphlops schmidti (Laurent, } \\
\text { 1956) }\end{array}$ & & & \\
\hline Schlegel's Blind Snake & $\begin{array}{l}\text { Afrotyphlops schlegelii } \\
\text { (Bianconi, 1847) }\end{array}$ & & $\begin{array}{l}\text { Typhlops petersii, } \\
\text { Typhlops humbo } \\
\text { \& Typhlops } \\
\text { hottentotus }\end{array}$ & \\
\hline Giant Blind Snake & $\begin{array}{l}\text { Afrotyphlops mucruso (Peters, } \\
1854)\end{array}$ & & Typhlops mucruso & \\
\hline $\begin{array}{l}\text { Leopoldville Beaked } \\
\text { Blind Snake }\end{array}$ & $\begin{array}{l}\text { Letheobia praeocularis } \\
\text { (Stejneger, 1894) }\end{array}$ & & & \\
\hline \multicolumn{5}{|l|}{ HENOPHIDIA | Pythonidae } \\
\hline Namib Dwarf Python & $\begin{array}{l}\text { Python anchietae (Bocage, } \\
1887 \text { ) }\end{array}$ & & Python anchietae & \\
\hline Southern African Python & $\begin{array}{l}\text { Python natalensis (Smith, } \\
1840 \text { ) }\end{array}$ & & Python natalensis & \\
\hline Northern African Python & $\begin{array}{l}\text { Python sebae (Gmelin, } \\
\text { 1789) }\end{array}$ & Y & & \\
\hline
\end{tabular}




\begin{tabular}{|c|c|c|c|c|}
\hline Common name & Scientific name & $\mathrm{C}$ & Bocage (1895) & Obs \\
\hline \multicolumn{5}{|c|}{ HENOPHIDIA / Colubridae I Colubrinae } \\
\hline White-lipped Snake & $\begin{array}{l}\text { Crotaphopeltis hotamboeia } \\
\text { (Laurenti, 1768) }\end{array}$ & $\mathrm{Y}$ & $\begin{array}{l}\text { Crotaphopeltis } \\
\text { rufescens }\end{array}$ & \\
\hline Barotse Water Snake & $\begin{array}{l}\text { Crotaphopeltis barotseensis } \\
\text { (Broadley, 1968) }\end{array}$ & & & NR \\
\hline Confusing Egg-eater & $\begin{array}{l}\text { Dasylepis confusa (Trape and } \\
\text { Mané, 2006) }\end{array}$ & & & NR \\
\hline Palm Egg-Eater & $\begin{array}{l}\text { Dasypeltis palmarum (Leach, } \\
1818 \text { ) }\end{array}$ & $\mathrm{Y}$ & $\begin{array}{l}\text { Dasypeltis scabra } \\
\text { var. palmarum }\end{array}$ & \\
\hline Rhombic Edd-Eater & $\begin{array}{l}\text { Dasypeltis scabra (Linnaeus, } \\
1758 \text { ) }\end{array}$ & & Dasypeltis scabra & \\
\hline Shreve's Tree Snake & $\begin{array}{l}\text { Dipsadoboa shrevei } \\
\text { (Loveridge, 1932) }\end{array}$ & & & \\
\hline Punctate Boomslang & $\begin{array}{l}\text { Dispholidus typus punctatus } \\
\text { (Laurent, 1955) }\end{array}$ & & $\begin{array}{l}\text { Bucephalus capensis } \\
\text { (part) }\end{array}$ & \\
\hline Green Boomslang & $\begin{array}{l}\text { Dispholidys } t \text {. viridis (Smith, } \\
\text { 1838) }\end{array}$ & & $\begin{array}{l}\text { Bucephalus capensis } \\
\text { (part) }\end{array}$ & \\
\hline Emerald Snake & $\begin{array}{l}\text { Hapsidophrys smaragdinus } \\
\text { (Schlegel, 1837) }\end{array}$ & $\mathrm{Y}$ & $\begin{array}{l}\text { Hapsidophrys } \\
\text { smaragdina }\end{array}$ & \\
\hline Angolan Green Snake & $\begin{array}{l}\text { Philothamnus angolensis } \\
\text { (Bocage, 1882) }\end{array}$ & $\mathrm{Y}$ & $\begin{array}{l}\text { Philothamnus } \\
\text { irregularis }\end{array}$ & \\
\hline $\begin{array}{l}\text { Thirteen-scaled Green } \\
\text { Snake }\end{array}$ & $\begin{array}{l}\text { Philothamnus carinatus } \\
\text { (Andersson, 1901) }\end{array}$ & & & \\
\hline Striped Green Snake & $\begin{array}{l}\text { Philothamnus dorsalis } \\
\text { (Bocage, 1866) }\end{array}$ & & $\begin{array}{l}\text { Philothamnus } \\
\text { dorsalis }\end{array}$ & \\
\hline Emerald Green Snake & $\begin{array}{l}\text { Philothamnus heterodermus } \\
\text { (Hallowell, 1857) }\end{array}$ & & $\begin{array}{l}\text { Philothamnus } \\
\text { heterodermus }\end{array}$ & \\
\hline Slender Green Snake & $\begin{array}{l}\text { Philothamnus heterolepidotus } \\
\text { (Günther, 1863) }\end{array}$ & & $\begin{array}{l}\text { Philothamnus } \\
\text { heterolepidotus }\end{array}$ & \\
\hline Southeastern Green Snake & $\begin{array}{l}\text { Philothamnus hoplogaster } \\
\text { (Günther, 1863) }\end{array}$ & & & \\
\hline Loveridge's Green Snake & $\begin{array}{l}\text { Philothamnus nitidus } \\
\text { loveridgei (Laurent, 1960) }\end{array}$ & & & \\
\hline Ornate Green Snake & $\begin{array}{l}\text { Philothamnus ornatus (Bocage, } \\
\text { 1872) }\end{array}$ & & $\begin{array}{l}\text { Philothamnus } \\
\text { ornatus }\end{array}$ & \\
\hline Spotted Bush Snake & $\begin{array}{l}\text { Philothamnus semivariegatus } \\
\text { (Smith, 1840) }\end{array}$ & & $\begin{array}{l}\text { Philothamnus } \\
\text { semivariegatus }\end{array}$ & \\
\hline $\begin{array}{l}\text { Large-eyed Green } \\
\text { Treesnake }\end{array}$ & $\begin{array}{l}\text { Rhamnophis aethiopissa } \\
\text { (Günther, 1862) }\end{array}$ & & & \\
\hline Hook-nosed Snake & $\begin{array}{l}\text { Scaphiophis albopunctatus } \\
\text { (Peters, 1870) }\end{array}$ & & $\begin{array}{l}\text { Scaphiophis } \\
\text { albopunctatus }\end{array}$ & \\
\hline Damara Tiger Snake & $\begin{array}{l}\text { Telescopus finkeldeyi (Haacke, } \\
\text { 2013) }\end{array}$ & & & \\
\hline Western Tiger Snake & $\begin{array}{l}\text { Telescopus polystictus } \\
\text { (Mertens, 1954) }\end{array}$ & & $\begin{array}{l}\text { Crotaphlopeltis } \\
\text { semiannulatus }\end{array}$ & \\
\hline Oates' Vine Snake & $\begin{array}{l}\text { Thelotornis capensis oatesi } \\
\text { (Günther, 1881) }\end{array}$ & & Thelotornis kirtlandii & \\
\hline
\end{tabular}




\begin{tabular}{|c|c|c|c|c|}
\hline Common name & Scientific name & $\mathrm{C}$ & Bocage (1895) & Obs \\
\hline Forest Vine Snake & $\begin{array}{l}\text { Thelotornis kirtlandii } \\
\text { (Hallowell, 1844) }\end{array}$ & & $\begin{array}{l}\text { Thelotornis } \\
\text { kirtlandii }\end{array}$ & \\
\hline Yellow-throated Treesnake & $\begin{array}{l}\text { Thrasops flavigularis } \\
\text { (Hallowell, 1852) }\end{array}$ & $\mathrm{Y}$ & \begin{tabular}{|l} 
Thrasops \\
flavigularis
\end{tabular} & \\
\hline Jackson's Treesnake & $\begin{array}{l}\text { Thrasops jacksoni (Günther, } \\
\text { 1895) }\end{array}$ & & & \\
\hline Blanding's Treesnake & $\begin{array}{l}\text { Toxicodryas blandingii } \\
\text { (Hallowell, 1844) }\end{array}$ & $\mathrm{Y}$ & Dipsas Blandingii & \\
\hline Powdered Treesnake & $\begin{array}{l}\text { Toxicodryas pulverulenta } \\
\text { (Fischer, 1856) }\end{array}$ & $\mathrm{Y}$ & Dipsas pulverulenta & \\
\hline \multicolumn{5}{|c|}{ HENOPHIDIA I Colubridae I Grayinae } \\
\hline Ornate Water Snake & Grayia ornata (Bocage, 1866) & Y & Grayia ornata & \\
\hline Smith's Water Snake & Grayia smithii (Leach, 1818) & & Grayia triangularis & \\
\hline Thollon's Water Snake & $\begin{array}{l}\text { Grayia tholloni (Mocquard, } \\
\text { 1897) }\end{array}$ & & & \\
\hline \multicolumn{5}{|l|}{ HENOPHIDIA | Natricidae } \\
\hline Bangweulu Swamp Snake & $\begin{array}{l}\text { Limnophis bangweolicus } \\
\text { (Mertens, 1936) }\end{array}$ & & & \\
\hline Striped Swamp Snake & $\begin{array}{l}\text { Limnophis bicolor (Günther, } \\
\text { 1865) }\end{array}$ & & Helocops bicolour & \\
\hline Broadley's Marsh Snake & $\begin{array}{l}\text { Natriciteres bipostocularis } \\
\text { (Broadley, 1962) }\end{array}$ & & & \\
\hline Olive Marsh Snake & $\begin{array}{l}\text { Natriciteres olivacea (Peters, } \\
\text { 1854) }\end{array}$ & $\mathrm{Y}$ & Mizodon olivaceus & \\
\hline
\end{tabular}

HENOPHIDIA | Lamprophiidae | Atractaspidinae

\begin{tabular}{|c|c|c|c|c|}
\hline $\begin{array}{l}\text { Common Purple-glossed } \\
\text { Snake }\end{array}$ & $\begin{array}{l}\text { Amblyodipsas polylepis } \\
\text { (Bocage, 1873) }\end{array}$ & & $\begin{array}{l}\text { Calamelaps } \\
\text { polylepis }\end{array}$ & \\
\hline $\begin{array}{l}\text { Kalahari Purple-glossed } \\
\text { Snake }\end{array}$ & $\begin{array}{l}\text { Amblyodipsas ventrimaculata } \\
\text { (Roux, 1907) }\end{array}$ & & & NR \\
\hline Cape Centipede Eater & $\begin{array}{l}\text { Aparallactus capensis (Smith, } \\
\text { 1849) }\end{array}$ & & Uriechis capensis & \\
\hline Birbon's Burrowing Asp & $\begin{array}{l}\text { Atractaspis bibronii (Smith, } \\
\text { 1849) }\end{array}$ & & Atractaspis Bibronii & \\
\hline Congo Burrowing Asp & $\begin{array}{l}\text { Atractaspis congica (Peters, } \\
\text { 1877) }\end{array}$ & $\mathrm{Y}$ & Atractaspis congica & \\
\hline Reticulate Burrowing Asp & $\begin{array}{l}\text { Atractaspis reticulata } \\
\text { heterochilus (Boulenger, 1901) }\end{array}$ & & & $\mathrm{RC}$ \\
\hline Wilson's burrowing snake & $\begin{array}{l}\text { Hypoptophis wilsoni } \\
\text { (Boulenger, 1908) }\end{array}$ & & & \\
\hline Collared Snake-Eater & Polemon collaris (Peters, 1881) & & Microsoma collare & \\
\hline $\begin{array}{l}\text { Bi-coloured Quill-snouted } \\
\text { Snake }\end{array}$ & $\begin{array}{l}\text { Xenocalamus bicolor } \\
\text { machadoi (Laurent, 1954) }\end{array}$ & & & \\
\hline $\begin{array}{l}\text { Elongate Quill-snouted } \\
\text { Snake }\end{array}$ & $\begin{array}{l}\text { Xenocalamus mechowii } \\
\text { mechowii (Peters, 1881) }\end{array}$ & & & \\
\hline $\begin{array}{l}\text { Inorante Elongate } \\
\text { Quill-snouted Snake }\end{array}$ & $\begin{array}{l}\text { Xenocalamus m. inorantus (de } \\
\text { Witte and Laurent, 1947) }\end{array}$ & & & \\
\hline
\end{tabular}




\begin{tabular}{|c|c|c|c|c|}
\hline Common name & Scientific name & $\mathrm{C}$ & Bocage (1895) & Obs \\
\hline \multicolumn{5}{|c|}{ HENOPHIDIA | Lamprophiidae | Lamprophiinae } \\
\hline Angolan House Snake & $\begin{array}{l}\text { Boaedon angolensis (Bocage, } \\
1895 \text { ) }\end{array}$ & & $\begin{array}{l}\text { Boodon lineatus var. } \\
\text { angolensis, Bocage, } \\
1895\end{array}$ & \\
\hline Brown House Snake & $\begin{array}{l}\text { Boaedon fuliginosus (Boie, } \\
\text { 1827) }\end{array}$ & & & \\
\hline Olive House Snake & $\begin{array}{l}\text { Boaedon olivaceus (Dumeril, } \\
1856 \text { ) }\end{array}$ & Y & Boodon olivaceus & \\
\hline $\begin{array}{l}\text { Red-Black Striped House } \\
\text { Snake }\end{array}$ & $\begin{array}{l}\text { Bothrophthalmus lineatus } \\
\text { (Peters, 1863) }\end{array}$ & & $\begin{array}{l}\text { Bothrophthalmus } \\
\text { lineatus }\end{array}$ & \\
\hline Parker's Banded Snake & $\begin{array}{l}\text { Chamaelycus parkeri (Angel, } \\
\text { 1934) }\end{array}$ & & & \\
\hline $\begin{array}{l}\text { Mocquard's Dwarf File } \\
\text { Snake }\end{array}$ & $\begin{array}{l}\text { Gonionotophis brusseauxi } \\
\text { (Mocquard, 1889) }\end{array}$ & & & \\
\hline Yellow Forest Snake & $\begin{array}{l}\text { Hormonotus modestus } \\
\text { (Duméril, Bibron and Duméril, } \\
1854 \text { ) }\end{array}$ & & & \\
\hline Western Forest File Snake & Mehelya poensis (Smith, 1849) & & & \\
\hline Cape File Snake & $\begin{array}{l}\text { Limaformosa capensis (Smith, } \\
\text { 1847) }\end{array}$ & & Heterolepis Guirali? & \\
\hline Savorgan's File Snake & $\begin{array}{l}\text { Limaformosa savorgani } \\
\text { (Moquard, 1887) }\end{array}$ & $?$ & & NR \\
\hline Vernay’s File Snake & $\begin{array}{l}\text { Limaformosa vernayi (Bogert, } \\
\text { 1940) }\end{array}$ & & & \\
\hline White-bellied Water Snake & $\begin{array}{l}\text { Lycodonomorphus (?) } \\
\text { subtaeniatus (Laurent, 1954) }\end{array}$ & & & \\
\hline Hellmich's Wolf Snake & $\begin{array}{l}\text { Lycophidion hellmichi } \\
\text { (Laurent, 1964) }\end{array}$ & & & \\
\hline Flat Wolf Snake & $\begin{array}{l}\text { Lycophidion laterale } \\
\text { (Hallowell, 1857) }\end{array}$ & & $\begin{array}{l}\text { Lycophidium } \\
\text { laterale }\end{array}$ & \\
\hline Speckled Wolf Snake & $\begin{array}{l}\text { Lycophidion meleagre } \\
\text { (Boulenger, 1893) }\end{array}$ & & $\begin{array}{l}\text { Lycophidium } \\
\text { meleagris }\end{array}$ & \\
\hline Spotted Wolf Snake & $\begin{array}{l}\text { Lycophidion multimaculatum } \\
\text { (Boettger, 1888) }\end{array}$ & $\mathrm{Y}$ & Lycophium capense & \\
\hline Namib Wolf Snake & $\begin{array}{l}\text { Lycophidion namibianum } \\
\text { (Broadley, 1991) }\end{array}$ & & & NR \\
\hline Ornate Wolf Snake & $\begin{array}{l}\text { Lycophidion ornatum (Parker, } \\
\text { 1936) }\end{array}$ & ? & & \\
\hline Viperine Rock Snake & $\begin{array}{l}\text { Hemirhagerrhis viperina } \\
\text { (Bocage, 1873) }\end{array}$ & & $\begin{array}{l}\text { Psammophylax } \\
\text { nototaenia }\end{array}$ & \\
\hline \multicolumn{5}{|c|}{ HENOPHIDIA | Lamprophiidae | Psammophinae } \\
\hline Angolan Sand Snake & $\begin{array}{l}\text { Psammophis angolensis } \\
\text { (Bocage, 1872) }\end{array}$ & & $\begin{array}{l}\text { Amphiophis } \\
\text { angolensis }\end{array}$ & \\
\hline Ansorge's Sand Snake & $\begin{array}{l}\text { Psammophis ansorgii } \\
\text { (Boulenger, 1905) }\end{array}$ & & & $\mathrm{E}$ \\
\hline Jalla's Sand Snake & $\begin{array}{l}\text { Psammophis jallae (Peracca, } \\
\text { 1896) }\end{array}$ & & & \\
\hline
\end{tabular}




\begin{tabular}{|c|c|c|c|c|}
\hline Common name & Scientific name & $\mathrm{C}$ & Bocage (1895) & Obs \\
\hline Leopard Sand Snake & $\begin{array}{l}\text { Psammophis leopardinus } \\
\text { (Bocage, 1887) }\end{array}$ & & & \\
\hline Namib Sand Snake & $\begin{array}{l}\text { Psammophis namibensis } \\
\text { (Broadley, 1975) }\end{array}$ & & & \\
\hline Karoo Sand Snake & $\begin{array}{l}\text { Psammophis notostictus } \\
\text { (Peters, 1867) }\end{array}$ & & & \\
\hline Mozambique Grass Snake & $\begin{array}{l}\text { Psammophis mossambicus } \\
\text { (Peters, 1882) }\end{array}$ & $\mathrm{Y}$ & $\begin{array}{l}\text { Psammophis } \\
\text { sibilans (Linnaeus, } \\
1758 \text { ) }\end{array}$ & \\
\hline Strip-bellied Sand Snake & $\begin{array}{l}\text { Psammophis subtaeniatus } \\
\text { (Peters, 1882) }\end{array}$ & & & \\
\hline Western Sand Snake & $\begin{array}{l}\text { Psammophis trigrammus } \\
\text { (Günther, 1865) }\end{array}$ & & & \\
\hline Fork-marked Sand Snake & $\begin{array}{l}\text { Psammophis trinasalis } \\
\text { (Werner, 1902) }\end{array}$ & & & \\
\hline Zambezi Sand Snake & $\begin{array}{l}\text { Psammophis zambiensis } \\
\text { (Hughes and Wade, 2000) }\end{array}$ & & & \\
\hline $\begin{array}{l}\text { Striped Beaked } \\
\text { Skaapstekker }\end{array}$ & $\begin{array}{l}\text { Psammophylax acutus } \\
\text { (Günther, 1888) }\end{array}$ & & Rhageheris acutus & \\
\hline Huila Skaapstekker & $\begin{array}{l}\text { Psammophylax ocellatus } \\
\text { (Bocage, 1873) }\end{array}$ & & $\begin{array}{l}\text { Psammophylax } \\
\text { rhombeatus }\end{array}$ & $\mathrm{E}$ \\
\hline Striped Skaapstekker & $\begin{array}{l}\text { Psammophylax tritaeniatus } \\
\text { (Günther, 1868) }\end{array}$ & & $\begin{array}{l}\text { Rhagerhis } \\
\text { tritaeniata }\end{array}$ & \\
\hline
\end{tabular}

HENOPHIDIA | Lamprophiidae I Prosymnidae

\begin{tabular}{l|l|l|l|l}
\hline $\begin{array}{l}\text { Zambezi Shovel-snout } \\
\text { Snake }\end{array}$ & $\begin{array}{l}\text { Prosymna ambigua (Bocage, } \\
1873)\end{array}$ & & Prosymna ambigua & \\
\hline $\begin{array}{l}\text { Angola Shovel-snout } \\
\text { Snake }\end{array}$ & $\begin{array}{l}\text { Prosymna angolensis } \\
\text { (Boulenger, 1915) }\end{array}$ & & Prosymna frontalis & \\
\hline South-west Shovel-snout & $\begin{array}{l}\text { Prosymna frontalis (Peters, } \\
1867)\end{array}$ & & \\
Snake & $\begin{array}{l}\text { Prosymna visseri (FitzSimons, } \\
1959)\end{array}$ & & \\
\hline Visser's Shivel-snout & & \\
Snake &
\end{tabular}

HENOPHIDIA | Lamprophiidae I Pseudaspidae

\begin{tabular}{l|l|l|l|l}
\hline Mole Snake & $\begin{array}{l}\text { Pseudaspis cana } \text { (Linnaeus, } \\
\text { 1758) }\end{array}$ & & Pseudaspis cana & \\
\hline Western-keeled Snake & $\begin{array}{l}\text { Pythonodipsas carinata } \\
\text { (Günther, 1868) }\end{array}$ & & & \\
\hline
\end{tabular}

HENOPHIDIA | Lamprophiidae I Elapidae

\begin{tabular}{l|l|l|l|l}
\hline Cowles' Shield Cobra & $\begin{array}{l}\text { Aspidelaps lubricus cowlesi } \\
\text { (Bogert, 1940) }\end{array}$ & & & \\
\hline Jameson's Mamba & $\begin{array}{l}\text { Dendroaspis jamesoni (Traill, } \\
1843)\end{array}$ & $?$ & $\begin{array}{l}\text { Dendroaspis } \\
\text { neglectus }\end{array}$ & \\
\hline Black Mamba & $\begin{array}{l}\text { Dendroaspis polylepis } \\
\text { (Günther, 1864) }\end{array}$ & $?$ & $\begin{array}{l}\text { Dendroaspis } \\
\text { angusticeps }\end{array}$ & \\
\hline Günther's Garter Snake & $\begin{array}{l}\text { Elapsoidea guentherii (Bocage, } \\
1866)\end{array}$ & & $\begin{array}{l}\text { Elapsoidea } \\
\text { Guentherii }\end{array}$ & \\
\hline
\end{tabular}




\begin{tabular}{|c|c|c|c|c|}
\hline Common name & Scientific name & $\mathrm{C}$ & Bocage (1895) & Obs \\
\hline Angolan Garter Snake & $\begin{array}{l}\text { Elapsoidea s. semiannulata } \\
\text { (Bocage, 1882) }\end{array}$ & & & \\
\hline Western Garter Snake & $\begin{array}{l}\text { Elapsoidea s. moebiusi } \\
\text { (Werner, 1897) }\end{array}$ & & & \\
\hline Anchiete's Cobra & $\begin{array}{l}\text { Naja (Ureaus) anchietae } \\
\text { (Bocage, 1879) }\end{array}$ & & $\begin{array}{l}\text { Naja anchietae \& } \\
\text { Naja haje }\end{array}$ & \\
\hline Banded Water Cobra & $\begin{array}{l}\text { Naja (Boulengerina) annulata } \\
\text { (Peters, 1876) }\end{array}$ & & & \\
\hline $\begin{array}{l}\text { Central African Forest } \\
\text { Cobra }\end{array}$ & $\begin{array}{l}\text { Naja (Boulengerina) } \\
\text { melanoleauca (Hallowell, } \\
\text { 1857) }\end{array}$ & & & \\
\hline Savanna Forest Cobra & $\begin{array}{l}\text { Naja (Boulengerina) subfulva } \\
\text { (Laurent, 1956) }\end{array}$ & $?$ & & \\
\hline Mozambique Cobra & $\begin{array}{l}\text { Naja (Afronaja) mossambica } \\
\text { (Peters, 1854) }\end{array}$ & & & \\
\hline $\begin{array}{l}\text { Western Banded Spitting } \\
\text { Cobra }\end{array}$ & $\begin{array}{l}\text { Naja (Afronaja) nigricincta } \\
\text { (Bogert, 1940) }\end{array}$ & & & \\
\hline Black Spitting Cobra & $\begin{array}{l}\text { Naja (Afronaja) nigricollis } \\
\text { (Reinhardt, 1843) }\end{array}$ & & Naja nigricollis & \\
\hline Gold's Tree Cobra & $\begin{array}{l}\text { Pseudohaje goldii (Boulenger, } \\
\text { 1895) }\end{array}$ & & & \\
\hline \multicolumn{5}{|l|}{ HENOPHIDIA / Viperidae } \\
\hline Variable Bush Viper & $\begin{array}{l}\text { Atheris squamigera (Hallowell, } \\
\text { 1854) }\end{array}$ & & Atheris squamigera & \\
\hline Puff Adder & Bitis arietans (Merrem, 1820) & & Vipera arietans & \\
\hline Horned Adder & Bitis caudalis (Smith, 1839) & & Vipera caudalis & \\
\hline Gaboon Adder & $\begin{array}{l}\text { Bitis gabonica Duméril, } \\
\text { (Bibron and Duméril, 1854) }\end{array}$ & $?$ & Vipera rhinoceros & \\
\hline Angolan Adder & Bitis heraldica (Bocage, 1889) & & Vipera heraldica & E \\
\hline Rhinoceros Viper & Bitis nasicornis (Shaw, 1802) & $?$ & & \\
\hline Peringuey's Adder & $\begin{array}{l}\text { Bitis peringueyi (Boulenger, } \\
\text { 1888) }\end{array}$ & $?$ & & \\
\hline Two-lined Night Adder & $\begin{array}{l}\text { Causus bilineatus (Boulenger, } \\
\text { 1905) }\end{array}$ & & & \\
\hline $\begin{array}{l}\text { Lichtenstein's Night } \\
\text { Adder }\end{array}$ & $\begin{array}{l}\text { Causus lichtensteini (Jan, } \\
1859 \text { ) }\end{array}$ & & & \\
\hline West African Night Adder & $\begin{array}{l}\text { Causus maculatus (Hallowell, } \\
1842 \text { ) }\end{array}$ & & & \\
\hline Rasmussen's Night Adder & $\begin{array}{l}\text { Causus rasmusseni (Broadley, } \\
\text { 2014) }\end{array}$ & & & \\
\hline $\begin{array}{l}\text { Angola Green Night } \\
\text { Adder }\end{array}$ & Causus resimus (Peters, 1862) & & Causus resimus & \\
\hline Rhombic Night Adder & $\begin{array}{l}\text { Causus rhombeatus } \\
\text { (Lichtenstein, 1823) }\end{array}$ & $\mathrm{Y}$ & Causus rhombeatus & \\
\hline
\end{tabular}

aDon't include the additional Boaedon species (Hallerman et al. in prep.) 


\section{References}

Adalsteinsson SA, Branch WR, Trapé S, Vitt LJ, Hedges SB (2009) Molecular phylogeny, classification, and biogeography of snakes of the family leptotyphlopidae (Reptilia, Squamata). Zootaxa 2244:1-50

Alexander AA, Gans C (1966) The pattern of dermal-vertebral correlation in snakes and amphisbaenians. Zool Med 41(11):171-190

Angel F (1921) Description d'un ophidien nouveau de l'Angola appartenant au genre Psammophis. Bull Soc Zool Fr Paris 46(8-10):116-118

Angel MF (1923) Reptiles. In: Rohan-Chabot (ed) Mission Rohan-Chabot, Angola et Rhodesia (1912-1914), Histoire Naturelle, Fascicule 1 (Mammifères - Oiseaux -Reptiles - Poissons), vol IV. Imprimerie Nationale, Paris, pp 157-169, 1 pl

Arruda M (2018) Confiscation by police of illegal soft-shell terrapin trade in Luanda. https://www. facebook.com/katimbala.ingles/videos/pcb.1576072472480736/1576072072480776/?type=3 \&theater

Baptista N, António T, Branch WR (2018) Amphibians and reptiles of the Tundavala region of the Angolan Escarpment. In: Revermann R, Krewenka KM, Schmiedel U et al (eds) Climate change and adaptive land management in southern Africa - assessments, changes, challenges, and solutions, Biodiversity \& ecology, vol 6. Klaus Hess Publishers, Göttingen, pp 397-403

Baptista N, Conradie W, Vaz Pinto P et al (2019) The Amphibians of Angola: early studies and the current state of knowledge. In: Huntley BJ, Russo V, Lages F, Ferrand N (eds) Biodiversity of Angola. Science \& conservation: a modern synthesis. Springer Nature, Cham

Bauer AM, Branch WR (2003) The herpetofauna of the Richterveld National Park and the adjacent northern Richtersveld, Northern Cape Province, Republic of South Africa. Herpetol Nat Hist $8(2): 111-160$

Bauer AM, Kuhn AL (2017) Historical climate change and the evolution of the Namib Day Geckos (Squamata: Gekkonidae: Rhoptropus) Oral Presentation (abst). Afr Herp News 66:9

Bauer AM, Lamb T (2005) Phylogenetic relationships of southern African geckos in the Pachydactylus group (Squamata: Gekkonidae). Afr J Herpetol 54(2):105-129

Billes A, Fretey J, Verhage B et al (2006) First evidence of leatherback movement from Africa to South America. Mar Turt Newsl 111:13-14

Blanc CP, Fretey J (2002) Analyse Zoogegraphique du peuplement reptilien de L'Afrique Centrale et de L'Angola. Biogeographica 78:49-75

Bocage JVB (1866) Lista dos reptis das possessões portuguesas d' Africa occidental que existem no Museu de Lisboa. J Sci Math Phys Nat Lisboa 1:37-56

Bocage JVB (1873) Reptiles nouveaux de l'interieur de Mossamedes. J Sci Math Phy Nat Lisboa 4:247-253

Bocage JVB (1895) Herpétologie d'Angola et du Congo. Lisbonne, Imprimerie Nationale, 203 pp, 19 pls

Bocage JVB (1896) Mammiferos, aves e reptis da Hanha, no sertào de Benguella. J Sci Math Phys Nat Lisboa 14(2):105-114

Bogert CM (1940) Herpetological results of the Vernay Angola Expedition. I. Snakes, including an arrangement of the African Colubridae. Bull Am Mus Nat Hist 77:1-107

Boulenger GA (1885) Catalogue of the lizards in the British Museum (Natural History). Volume II, Iguanidae, Xenosauridae, Zonuridae, Anguidae, Anniellidae, Helodermatidae, Varanidae, Xantusiidae, Teiidae, Amphisbaenidae. London: British Museum of (Natural History), London, xiv + 492 pp, 54 figs., 24 pls

Boulenger GA (1893) Catalogue of the snakes in the British Museum (Natural History). Volume I, containing the families Typhlopidae, Glauconiidae, Boidae, Ilysiidae, Uropeltidae, Xenopeltidae and Colubridae aglyphae, part. British Museum (Natural History), London, xiv + 448 pp, 26 figs., 28 pls 
Boulenger GA (1894) Catalogue of the snakes in the British Museum (Natural History). Volume II, containing the conclusion of the Colubridae aglyphae. British Museum (Natural History), London, xii + 382 pp, 25 figs., 20 pls

Boulenger GA (1896) Catalogue of the snakes in the British Museum (Natural History). Volume III, containing the Colubridae (Opisthoglyphae and Proteroglyphae), Amblycephalidae, and Viperidae. British Museum (Natural History), London, xiv + 727 pp, 37 figs., 25 pls

Boulenger GA (1905) A list of the batrachians and reptiles collected by Dr. W. J. Ansorge in Angola, with descriptions of new species. Ann Mag Nat Hist Ser 7 16:105-115

Boulenger GA (1907a) Descriptions of three new lizards and a frog, discovered by Dr. W. J. Ansorge in Angola. Ann Mag Nat Hist Seventh Ser 19:212-214

Boulenger GA (1907b) Descriptions of a new frog discovered by Dr. W. J. Ansorge in Mossamedes, Angola. Ann Mag Nat Hist Seventh Ser 20:109

Boulenger GA (1915) A list of the snakes of the Belgian and Portuguese Congo, northern Rhodesia, and Angola. Proc Zool Soc London 1915:193-223

Bowker JN, De Vos A, Ament JM et al (2017) Effectiveness of Africa's tropical protected areas for maintaining forest cover. Conserv Biol 31(3):559-569

Branch WR (1994) Herpetofauna of the Sperrgebeit region of southern Namibia. Herpetol Nat Hist 2(1):1-11

Branch WR (2014) Reptiles of South Africa, Lesotho and Swaziland: conservation status, diversity, endemism, hotspots and threats. In: Bates MF, Branch WR, Bauer AM, Burger M, Marais J, Alexander GJ, de Villiers MS (eds) Atlas and Red Data Book of the Reptiles of South Africa, Lesotho and Swaziland, Suricata 1. South African National Biodiversity Institute, Pretoria, pp 22-50

Branch WR (2016) Preface, amphibian \& reptile conservation special Angola-Africa issue. Amphib Rep Conserv 10(2):2. i-iii

Branch WR (2018) Snakes of Angola: an annotated checklist. Amphibian \& Reptile Conservation 12(2) [General Section]: 41-82 (e159)

Branch WR, Conradie W (2013) Naja annulata annulata (Bucholtz \& Peters, 1876). African Herp News 59:50-53

Branch WR, Conradie WC (2015) Vl Herpetofauna da regiáo da Lagoa Carumbo (Herpetofauna of the Carumba Lagoon Area). In: Huntley B \& Francisco P (eds) Relatório sobre a Expedição Avaliação rápida da Biodiversidade de regiáo da Lagoa Carumbo, Lunda-Norte - Angola, pp 194-209. Republica de Angola Ministerio do Ambiente, 219p

Branch WR, McCartney CJ (1992) A report on a small collection of reptiles from southern Angola. J Herpetol Assoc Afr 41:1-3

Branch WR, Tolley KA (2017) Oral presentation (abst). New Lacertids from Angola. Afr Herp News 66:11

Branch WR, Haacke W, Vaz Pinto P et al (2017) Loveridge's Angolan geckos, Afroedura karroica bogerti and Pachydactylus scutatus angolensis (Sauria, Gekkonidae): new distribution records, comments on type localities and taxonomic status. Zoosyst Evol 93(1):157-166

Branch WR, Baptista N, Vaz Pinto P (2018) Angolan amphisbaenians: rediscovery of Monopeltis luandae Gans 1976, with comments on the type locality of Monopeltis perplexus Gans 1976 (Sauria: Amphisbaenidae). Herpetology Notes 11:603-606

Branch WR, Baptista N, Keates C et al (2019) Rediscovery, taxonomic status and phylogenetic relationships of two enigmatic Psammophine snakes (Serpentes: Psammophinae) from the southwestern Angola plateau. Zootaxa (in press)

Broadley DG (1971) A revision of the African snake genera Amblyodipsas and Xenocalamus. Occ Pap Natl Mus Rhod B4(33):629-697

Broadley DG (1975) A review of the Mabuya lacertiformis complex in southern Africa (Sauria: Scincidae). Arnoldia (Rhod) 7(18):1-16

Broadley DG (1991) The Herpetofauna of Northern Mwinilunga Distr., Northw. Zambia. Arnoldia Zimbabwe 9(37):519-538 
Broadley DG (1996) A review of the tribe Atherini (Serpentes: Viperidae), with the descriptions of two new genera. Afr J Herpetol 45:40-48

Broadley DG (1997a) A review of the Monopeltis capensis complex in southern Africa (Reptilia: Amphisbaenidae). Afr J Herpetol 46(1):1-12

Broadley DG (1997b) Amphibaenia. Dalophia ellenbergeri (Angel, 1920). African Herp News 26:34-35

Broadley DG (2001) Geographical distribution. Monopeltis sphenorhynchus. Afr Herp News 32:23-24

Broadley DG, Baldwin AS (2006) Taxonomy, natural history, and zoogeography of the Southern African Shield Cobras, Genus Aspidelaps (Serpentes: Elapidae). Herpetol Nat Hist 9(2):163-176

Broadley DG, Broadley S (1999) A review of the African worm snakes from south of latitude $12^{\circ} \mathrm{S}$ (Serpentes: Leptotyphlopidae). Syntarsus 5:1-36

Broadley DG, Gans C (1969) A new species of Zygaspis (Amphisbaenia: Reptilia) from Zambia and Angola. Arnoldia (Rhod) 4(25):1-4

Broadley DG, Hughes B (2000) A revision of the African genus Hemirhagerrhis Boettger 1893 (Serpentes: Colubridae). Syntarsus 6:1-17

Broadley DG, Schätti B (2000) A new species of Coluber from northern Namibia (Reptilia: Serpentes). Modoqua 19(2):171-174

Broadley DG, Gans C, Visser J (1976) Studies on Amphisbaenians (6). The Genera Monopeltis and Dalophia in Southern Africa. Bull Am Mus Nat Hist 157(5):311-486

Broadley DG, Tolley KA, Conradie W et al (2018) A phylogeny and revision of the African File Snakes Gonionotophis Boulenger (Squamata: Lamprophiidae). Afr J Herpetol. https://doi.org/ 10.1080/21564574.2018.1423578

Brooks C (2012) Biodiversity survey of the upper Angolan Catchment of the Cubango-Okavango River Basin. USAid-Southern Africa, $151 \mathrm{p}$

Brooks C (2013) Trip report: aquatic biodiversity survey of the lower Cuito and Cuando river systems in Angola. USAid-Southern Africa. $43 \mathrm{p}$

Carr T, Carr P (1991) Surveys of the sea turtles of Angola. Biol Conserv 58(1):19-29

CEPF (2003) Ecosystem profile. The succulent Karoo hotspot, Namibia and South Africa. Critical ecosystem partnership fund. South African National Biodiversity Institute. https://www.sanbi. org/documents/ecosystem-profile-succulent-karoo-hotspot

Ceríaco LMP, Bauer AM, Blackburn DC et al (2014a) The herpetofauna of the Capanda Dam Region, Malanje, Angola. Herpetol Rev 45(4):667-674

Ceríaco LMP, Blackburn DC, Marques MP et al (2014b) Catalogue of the amphibian and reptile type specimens of the Museu de História Natural da Universidade do Porto in Portugal, with some comments on problematic taxa. Alytes 31(1):13-36

Ceríaco LMP, de Sá SAC, Bandeira S, Valério H et al (2016a) Herpetological survey of Iona National Park and Namibe Regional Natural Park, with a Synoptic list of the Amphibians and reptiles of Namibe Province, Southwestern Angola. Proc Calif Acad Sci 63(2):15-61

Ceríaco LMP, Marques MP, Bandeira SA (2016b) Anfíbios e Répteis do Parque Nacional da Cagandala. Publ. Instituto Nacional da Biodiversidade e Áreas de Conservação \& Museu Nacional de História Natural e da Ciência, 96 p

Ceríaco LMP, de Sá S, Bauer AM (2018a) The genus Osteolaemus (Crocodylidae) in Angola and a new southernmost record for the genus. Herpetol Notes 11:337-341

Ceríaco LMP, Marques MP, Bandeira S et al (2018b) Herpetological survey of Cangandala National Park, with a synoptic list of the amphibians and reptiles of Malanje Province, Central Angola. Herpetol Rev 49(3):408-431

Clark VR, Barker NP, Mucina L (2011) The great escarpment of southern Africa: a new frontier for biodiversity exploration. Biodivers Conserv 20:2543-2561

Conradie W, Bourquin S (2013) Geographical Distributions: Acontias kgalagadi kgalagadi (Lamb, Biswas and Bauer, 2010). Afr Hep News 60:29-30 
Conradie W, Branch WR, Measey GJ et al (2012a) Revised phylogeny of Sand lizards (Pedioplanis) and the description of two new species from south-western Angola. Afr J Herpetol 60(2):91-112

Conradie W, Branch WR, Measey JG et al (2012b) A new species of Hyperolius Rapp, 1842 (Anura: Hyperoliidae) from the Serra da Chela mountains, southwestern Angola. Zootaxa 3269:1-17

Conradie W, Branch WR, Tolley KA (2013) Fifty shades of grey: giving colour to the poorly known Angolan Ash reed frog (Hyperoliidae: Hyperolius cinereus), with the description of a new species. Zootaxa 3635(3):201-223

Conradie W, Bills R, and Branch WR (2016). The herpetofauna of the Cubango, Cuito, and lower Cuando river catchments of south-eastern Angola. Amphibian Reptile Conserv 10(2) [Special Section]:6-36

Conradie WC, Bills R, Baptista N et al (2017) Oral presentation (abst). Across river basins: Exploring the unknown southeastern Angola. African Herp News 66:14-15

Cotterill F, De Wit M (2011) Geoecodynamics and the Kalahari Epeirogeny: linking its genomic record, tree of life and palimpsest into a unified narrative of landscape evolution. S Afr J Geol 114:489-514

Craven P (2009) Phytogeographic study of the Kaokoveld Centre of Endemism. Unpublished Ph.D. thesis, University of Stellenbosch, $234 \mathrm{p}$

Crawford-Cabral J, Mesquitela LM (1989) Índice toponímico de colheitas zoológicas em Angola. Instituto de Investigação Cientifica Tropical. Centro de Zoologia, Lisbon 206 pp

De Almeida MAP (2011) José Vicente Barbosa du Bocage. In: Biographies of scientists and engineers, Centro Interuniversitário de História da Ciência e Tecnologia. http://ciuhct.org/pt/ bocage-jose-vicente-barbosa-du

Eaton MJ (2010) Dwarf crocodile Osteolaemus tetraspis. In: Manolis SC, Stevenson C (eds) Crocodiles. Status survey and conservation action plan, 3rd edn. Crocodile Specialist Group, Darwin, pp 127-132

Eaton MJ, Martin A, Thorbjarnarson J, Amato G (2009) Species-level diversification of African dwarf crocodiles (genus Osteolaemus): a geographic and phylogenetic perspective. Mol Phylogenet Evol 50(3):496-506

Elwen S, Braby RJ (2015) Report on a turtle and cetacean assessment survey to the Kunene River mouth, northern Namibia - January 2014. Afr Sea Turtle Newsl 4:22-27

Engelbrecht HM, Branch WR, Greenbaum E et al (2018) Diversifying into the branches: species boundaries in African green and bush snakes, Philothamnus (Serpentes: Colubridae). Mol Phylo Evol. https://doi.org/10.1016/j.ympev.2018.10.023

Ernst R (2015) A rapid assessment of the herpetofauna of the Serra do Pingano ecosystem in Uíge Province, northern Angola. Unpubl. Report to Instituto Nacional da Biodiversidade e Áreas de Conservação, Ministério do Ambiente, República de Angola, 11 p

Ernst R, Nienguesso ABT, Lautenschläger T et al (2014) Relicts of a forested past: southernmost distribution of the hairy frog genus Trichobatrachus Boulenger, 1900 (Anura: Arthroleptidae) in the Serra do Pingano region of Angola with comments on its taxonomic status. Zootaxa 3779(2):297-300

Ernst R, Schmitz A, Wagner P et al (2015) A window to Central African forest history: distribution of the Xenopus fraseri subgroup south of the Congo Basin, including a first country record of Xenopus andrei from Angola. Salamandra 52(1):147-155

Face of Malawi (2013) Chinese 'managed' Turtle butchery discovered on Lake Malawi. http://www. faceofmalawi.com/2013/11/chinese-managed-turtle-butchery-discovered-on-lake-malawi/

Ferreira JB (1897) Lista dos reptis e amphibios que fazem parte da última remessa de J. d'Anchieta. J Sci Math Phys Nat Lisboa 5(2):240-246

Ferreira JB (1900) Sobre alguns exemplares pertencentes á fauna do norte de Angola. J Sci Math Phys Nat Lisboa 21:48-54

Ferreira JB (1903) Reptis de Angola da região norte do Quanza da collecção Pereira do Nascimento (1902). J Sci Math Phys Nat Lisboa Segunda Série 7(25):9-16

Ferreira JB (1904) Reptis e amphibios de Angola da região ao norte do Quanza (Collecção Newton - 1903). J Sci Math Phys Nat Lisboa Segunda Série 7(26):111-117 
Ferreira JB (1906) Algumas espécies novas ou pouco conhecidas de amphibios e reptis de Angola (Collecção Newton - 1903). J Sci Math Phys Nat Lisboa Segunda Série 7(26):159-171

FitzSimons VFM (1953) A new genus of gerrhosaurid from southern Angola. Ann Transv Mus 22(2):215-217

FitzSimons VFM (1959) Some new reptiles from southern Africa and southern Angola. Ann Transv Mus 23(4):405-409

Gamito-Marques D (2017) A space of one's own: Barbosa du Bocage, the foundation of the National Museum of Lisbon, and the construction of a career in zoology (1851-1907). J Hist Biol. https://doi.org/10.1007/s10739-017-9487-6

Gans C (1976) Three new spade-snoted amphisbaenians from Angola (Amphisbaenia, reptilia). Am Mus Novit 2590:1-11

Gans C (2005) Checklist and bibliography of the Amphisbaenia of the World. Bull Am Mus Nat Hist 289(1):130

Gray JE (1865) A revision of the genera and species of amphisbaenians with the descriptions of some new species now in the collection of the British Museum. Proc Zool Soc London 1865:442-455

Greenbaum E, Portillo F, Jackson K et al (2015) A phylogeny of central African Boaedon (Serpentes: Lamprophiidae), with the description of a new cryptic species from the Albertine Rift. Afr J Herpetol 64(1):18-38

Haacke WD (1976a) The burrowing geckos of southern Africa, 2 (Reptilia: Gekkonidae). Ann Transv Mus 30(2):13-29

Haacke WD (1976b) The burrowing geckos of southern Africa, 3 (Reptilia: Gekkonidae). Ann Transv Mus 30(3):29-44

Haacke WD (1981) The file snakes of the genus Mehelya in Southern Africa with special reference to South West Africa/Namibia. Modoqua 12(4):217-224

Haacke WD (1997) Systematics and biogeography of the southern African scincine genus Typhlacontias (Reptilia: Scincidae). Bonner Zool Beiträge 47(1-2):139-163

Haacke WD (2008) A new leaf-toed gecko (Reptilia: Gekkonidae) from south-western Angola. Afr J Herpetol 57:85-92

Haacke WD (2013) Description of a new Tiger Snake (Colubridae, Telescopus) from south-western Africa. Zootaxa 3737(3):280-288

Haagner GV, Branch WR, Haagner AJF (2000) Notes on a collection of reptiles from Zambia and adjacent areas of the Democratic Republic of the Congo. Ann East Cape Mus 1:1-25

Heinicke MP, Daza JD, Greenbaum E et al (2014) Phylogeny, taxonomy and biogeography of a circum-Indian Ocean clade of leaf-toed geckos (Reptilia: Gekkota), with a description of two new genera. Syst Biodivers 12(1):23-42

Heinz HM (2011) Comparative phylogeography of two widespread geckos from the typically narrow-ranging Pachydactylus group in Southern Africa. Unpublished MSc thesis, Villanova University, Villanova, Pennsylvania, USA, vii + 107 pp

Hellmich W (1954-1955) Auf herpetologischer Forschungsfahrt in Angola (Portugeisisch Westafrika). Die Aquarien und Terrarien Zeitschrift. In six parts: 1954 - I, 7(11): 302-304; II, 7(12): 324-326; 1955 - III, 8(1): 23-26; IV, 8(2): 51-53; V, 8(3):78-81; VI, 8(4):103-107

Hellmich W (1957a) Die reptilienausbeute der Hamburgischen Angola Expedition. Mitteilungen aus dem Hamburgischen Zoologischen Museum und Institut 55:39-80

Hellmich W (1957b) Herpetologische Ergebnisse einer Forschungsreise in Angola. Veröffentlichungen der Zoologischen Staatssammlung München 5:1-92

Hellmich W, Schmelcher D (1956) Eine neue Rasse von Gerrhosaurus nigrolineatus Hallowell (Gerrhosauridae). Zool Anz 156(7/8):202-205

Herrmann H-W, Branch WR (2013) Fifty years of herpetological research in the Namib Desert and Namibia with an updated and annotated species checklist. J Arid Environ 93:94-115

Huntley BJ (1974) Outlines of wildlife conservation in Angola. J S Afr Wildl Manage Assoc 4:157-166 
Huntley BJ (2009) SANBI/ISCED/UAN Angolan biodiversity assessment capacity building project. Report on Pilot project. Unpublished report to ministry of environment, Luanda, $97 \mathrm{pp}$, 27 figures

Huntley BJ (2019) Angola in outline: physiography, climate and patterns of biodiversity. In: Huntley BJ, Russo V, Lages F, Ferrand N (eds) Biodiversity of Angola. Science \& conservation: a modern synthesis. Springer Nature, Cham

Huntley BJ, Francisco P (eds) (2015) Relatório sobre a Expedição Avaliação rápida da Biodiversidade de regiáo da Lagoa Carumbo, Lunda-Norte - Angola/Biodiversity Rapid Assessment of the Carumbo Lagoon Area, Lunda-Norte. Angola Ministerio do Ambiente, Luanda $219 \mathrm{pp}$

Jordan K (1936) Dr Karl Jordan's expedition to South-West Africa and Angola. Narrat Nov Zool 40:17-62, 2 maps, 5 pls

Jongsma GFM, Barej MF, Barratt CD, Burger M, Conradie W, Ernst R, Greenbaum E, Hirschfeld M, Leaché AD, Penner J, Portik DM, Zassi-Boulou A-G, Rödel M-O, Blackburn DC (2018) Diversity and biogeography of frogs in the genus Amnirana (Anura: Ranidae) across sub-Saharan Africa. Mol Phylogenet Evol 120:274-285

Kelly CMR, Branch WR, Broadley DG et al (2011) Molecular systematics of the African snake family Lamprophiidae Fitzinger, 1843 (Serpentes: Elapoidea), with particular focus on the genera Lamprophis Fitzinger 1843 and Mehelya Csiki 1903. Mol Phylogenet Evol 58:415-426

Kindler C, Branch WR, Hofmeyr MF et al (2012) Molecular phylogeny of African hinge-back tortoises (Kinixys Bell, 1827): implications for phylogeography and taxonomy (Testudines: Testudinidae). J Zool Syst Evol Res 50(3):192-201

Laurent RF (1950) Reptiles et Batraciens de la region de Dundo (Angola du Nord-Est). Publicações culturais da Companhia de Diamantes de Angola 10:7-17

Laurent RF (1954) Reptiles et Batraciens de la région de Dundo (Angola) (Deuxième Note). Publicações culturais da Companhia de Diamantes de Angola 23:35-84

Laurent RF (1964) Reptiles et Amphibiens de l'Angola (Troisième contribution). Publicações culturais da Companhia de Diamantes de Angola 67:11-165

Lewin A, Feldman A, Bauer AM et al (2016) Patterns of species richness, endemism and environmental gradients of African reptiles. J Biogeogr 43:2380-2390

Lindsey PA, Nyirenda VR, Barnes JI et al (2014) Underperformance of African protected area networks and the case for new conservation models: insights from Zambia. PLoS One 9(5):e94109

Loveridge A (1941) Revision of the African lizards of the family Amphisbaenidae. Bull Mus Comp Zool 87(5):353-451

Loveridge A (1944) New geckos of the genera Afroedura, new genus, and Pachydactylus from Angola. Am Mus Novit 1254:1-4

Machado AdB (1952) Generalidades acerca da Lunda e da sua exploraçao biolôgica. Publ. Cult. Comp. Diam. Angola, 12

Madruga CM (2013) José Vicente Barbosa du Bocage (1823-1907): a construção de uma persona científica. Unpublished M.Sc. thesis, Universidade de Lisboa

Manaças S (1963) Sáurios de Angola. Memórias da Junta de Investigações do Ultramar, Lisboa, 43, segunda série. Estudos Zool:223-240

Manaças S (1973) Alguns ofídeos de Angola. Memórias da Junta de Investigações do Ultramar, Lisboa, 58, segunda série. Estudos de Zoologia:187-200

Manaças S (1981) Ofídeos venenosos da guiné, S. Tomé, Angola e Moçambique. Garcia Orta Sér de Zool 10(1/2):13-46

Marques MP, Ceríaco LMP, Bauer AM, et al. (2014) Geographic distribution of Amphibians and reptiles of Angola: towards an Atlas of Angolan herpetofauna. Poster. 12th Herpetological association of Africa conference, Gobabeb, Namibia, 20-22 November, 2014

Marques MP, Ceríaco LMP, Blackburn DC, Bauer AM (2018) Diveristy and distribution of the amphibians and terrestrail reptiles of Angola atlas of historical and bibliographic records (1840-2017). Proceedings of the California academy of sciences, Series 4, Volume 65, Supplement II: $1-501$ 
Marx H (1956) A new lacertid lizard from Angola. Fieldiana: Zoology 39:5-9

Mateus O, Jacobs L, Polcyn M (2009) The oldest African eucryptodiran turtle from the Cretaceous of Angola. Acta Palaeontol Pol 54(4):581-588

McLachlan GR, Spence JM (1967) A new species of Pachydactylus (Pachydactylus oreophilus sp. nov.) from Sesfontein, South West Africa. Cimbebasia (21):3-8

Measey J, Tolley KA (2013) A molecular phylogeny for sub-Saharan amphisbaenians. Afr J Herpetol 62(2):100-108

Medina MF, Bauer AM, Branch WR et al (2016) Molecular phylogeny of Panaspis and Afroablepharus skinks (Squamata: Scincidae) in the savannas of sub-Saharan Africa. Mol Phylogenet Evol 100:409-423

Mertens R (1938) Amphibien und Reptilien aus Angola, gesammelt von W. Schack. Senckenbergiana 20:425-443

Mertens R (1958) Bitis heraldica, eine oft verkannte Otter aus Angola. Senckenbergiana Biologica Frankfurt-am-Main 39(3-4):145-148, 4 figs

Monard A (1931) Mission scientifique Suisse dans l'Angola. Résultats scientifiques. Reptiles. Bull Soc Neuchâtel Sci Nat ser 2 40(55):89-111

Monard A (1934) Ornithologie de l'Angola. Arquivos do Museu Bocage 5:1-110

Monard A (1935) Contribution à la mammologie d'Angola et prodrome d'une faune d'Angola. Arquivos do Museu Bocage 6:1-314 44 fig

Monard A (1937) Contribution á l'herpétologie d'Angola. Arquivos do Museu Bocage 8:19-154

Monard A (1938) Contribution à la batrachologie d'Angola. Bull Soc Neuch Se Nat 62:5-59, 19 fig

Morais M (2008) Tartarugas Marinhas na Costa de Cabinda. Plano de conservação e gestão para a implementação do projecto de prospecção sísmica "on shore". Holisticos/Chevron. $67 \mathrm{p}$

Morais M (2016) Projecto Kitabanga - Conservação de tartarugas marinhas. Relatório final da temporada 2015/2016. Universidade Agostinho Neto/Faculdade de Ciências, Luanda

Morais M (2017) Projecto Kitabanga - Conservação de tartarugas marinhas. Relatório final da temporada 2016/2017. Universidade Agostinho Neto / Faculdade de Ciências, Luanda

Morais M, Torres MOF, Martins MJ (2005) Análise da Biodiversidade Marinha e Costeira e Identificação das Pressões de Origem Humana sobre os Ecossistemas Marinhos e Costeiros. Ministerio do Urbanismo e Ambiente, Luanda, $140 \mathrm{pp}$

Nagy ZT, Kusamba C, Collet M et al (2013) Notes on the herpetofauna of western Bas-Congo, democratic Republic of the Congo. Herpetology Notes 6:413-419

NGOWP (2018) National geographic Okavango wilderness project. Initial findings from exploration of the upper catchments of the Cuito, Cuanavale, and Cuando Rivers, May 2015-December 2016

NPAES (2010) National protected area expansion strategy for South Africa 2008. Priorities for expanding the protected area network for ecological sustainability and climate change adaptation. Government of South Africa, Pretoria

OKACOM (2011) National action plan for the sustainable management of the Cubango/Okavango River Basin, Angola - Draft 3. Available http://www.okacom.org/site-documents. Accessed 24 June 2016

Oliveira PRS d (2017) Sepentes em Angola. Uma visão toxinolŏgca e clínica dos envenenamentos. Glaciar, Lisbon, p 159

Oliveira PRS d, Rocha MT, Castro AG et al (2016) New records of Gaboon viper (Bitis gabonica) in Angola. Herpetol Bull 136:42-43

Parker HW (1936) Dr. Karl Jordan's expedition to South West Africa and Angola: herpetological collection. Nov Zool 40:115-146

Peters WCH (1869) Eine Mittheilung über neue Gattungen und Arten von Eidechsen. Monatsber Königl Preuss Akad Wissensch Berlin 1869:57-66

Peters WCH (1876) Über die von Hrn. Professor Dr. R. Buchholz in Westafrika gesammelten Amphibien. Auszug aus dem Monatsberich der Königl. Akademie der Wissenschafen zu Berlin:117-124 
Peters WCH (1877) Übersicht der Amphibien aus Chinchoxo (Westafrika), welche von der Africanischen Gesellschaft dem Berliner zoologischen Museum übergeben sind. Monatsberichte der königlich Akademie der Wissenschaften zu Berlin 10:611-620

Peters WCH (1881) Zwei neue von Herrn Major von Mechow während seiner letzten Expedition nach West-Afrika entdeckte Schlangen und eine Übersicht der von ihm mitgebrachten herpetologischen Sammlung. Sitzungsberichte der Gesellschaft Naturforschender Freunde zu Berlin 9:147-150

Pietersen DW, Pietersen EW, Conradie W (2017) Preliminary herpetological survey of Ngonye falls and surrounding regions in southwestern Zambia. Amphibian Reptile Conserv 11(1) [Special Section]:24-43

Pincheira-Donoso D, Bauer AM, Meiri S, Uetz P (2013) Global taxonomic diversity of living reptiles. PLoS One 8(3):e59741

Portillo F, Branch WR, Conradie W et al (2018) Phylogeny and biogeography of the African burrowing snake subfamily Aparallactinae (Squamata: Lamprophiidae). Mol Phylogenet Evol 127:288-303

Poynton JC, Haacke WD (1993) On a collection of amphibians from Angola including a new species of Bufo Laurenti. Ann Transv Mus 36(2):9-16

Roll U, Feldman A, Novosolov M et al (2017) The global distribution of tetrapods reveals a need for targeted reptile conservation. Nat Ecol Conserv 1:1677-1682

Schmidt KP (1933) The reptiles of the Pulitzer-Angola expedition. Ann Carnegie Mus 22:1-15

Schmidt KP (1936) The amphibians of the Pulitzer-Angola expedition. Ann Carnegie Mus 25:127-133

Shirley MH, Vliet KA, Carr AN et al (2014) Rigorous approaches to species delimitation have significant implications for African crocodilian systematics and conservation. Proc R Soc B 281:20132483

Shirley MH, Carr AN, Nestler JH et al (2018) Systematic revision of the living African slendersnouted crocodiles (Mecistops Gray, 1844). Zootaxa 4504:151-193

Stanley EL, Ceríaco LMP, Bandeira S et al (2016) A review of Cordylus machadoi (Squamata: Cordylidae) in southwestern Angola, with the description of a new species from the Pro-Namib desert. Zootaxa 4061(3):201-226

Tilbury C (2018) Chameleons of Africa: an atlas, including the Chameleons of Europe, the Middle East and Asia. Edition Chimaira, Frankfurt M, $831 \mathrm{pp}$

Tolley KA, Alexander GJ, Branch WR et al (2016) Conservation status and threats for African reptiles. Biol Conserv 204:63-67

Trape J-F, Mediannikov O (2016) Cinq serpents nouveaux du genre Boaedon Duméril, Bibron \& Duméril, 1854 (Serpentes : Lamprophiidae) en Afrique centrale. Bull Soc Herp France 159:61-111

TRIPLOV (2018) Publications José Vincente Barbosa du Bocage. http://www.triplov.com/biblos/ bocage.htm

TTWG Turtle Taxonomy Working Group (2011) Turtle conservation Coalition. Turtles in trouble: the world's 25+ most endangered tortoises and freshwater turtles. Chelonian Research Foundation, Conservation International, Wildlife Conservation Society, and San Diego Zoo Global, 54 pp

TTWG Turtle Taxonomy Working Group (2017) Turtles of the world: annotated checklist and atlas of taxonomy, synonymy, distribution, and conservation status (8th Ed.). Chelonian Res Monogr 7:1-292

Tys van den Audenaerde DFE (1967) Les serpents des environs de Dundo (Angola) (Note complémentaire). Publicações culturais da Companhia de Diamantes de Angola 76:31-37

Uetz P, Freed P, Hošek J (eds) (2018) The reptile database. Available http://www.reptile-database. org. Accessed 11 Jan 2018

Vaz Pinto P, Branch WR (2015) Geographical distribution: Dendroaspis jamesoni (Thraill, 1843), Jameson's Mamba. African Herp News 62:45-47

Uetz P, Stylianou A (2018) The original descriptions of reptiles and their subspecies. Zootaxa 4375(2):257 
Wagner P, Böhme W, Pauwels OSG, Schmitz A (2009) A review of the African red-flanked skinks of the Lygosoma fernandi (Burton, 1836) species group (Squamata: Scincidae) and the role of climate change in their speciation. Zootaxa 2050:1-30

Wagner P, Bauer AM, Wilms TM et al (2012) Miscellanea accrodontia: notes on nomenclature, taxonomy and distribution. Russ J Herpetol 19:177-189

Wagner P, Greenbaum E, Bauer AM et al (2018) Lifting the blue-headed veil - integrative taxonomy of the Acanthocercus atricollis species complex (Squamata: Agamidae). J Nat Hist. https://doi.org/10.1080/00222933.2018.1435833

Weinell JL, Bauer AM (2018) Systematics and phylogeography of the widely distributed African skink Trachylepis varia species complex. Mol Phylogenet Evol 120:103-117

Weir CR, Ron T, Morais M et al (2007) Nesting and at-sea distribution of marine turtles in Angola, West Africa, 2000-2006: occurrence, threats and conservation implications. Oryx 41(2):224-231

Wüster W, Chirio L, Trape J-F et al (2018) Integration of nuclear and mitochondrial gene sequences and morphology reveals unexpected diversity in the forest cobra (Naja melanoleuca) species complex in Central and West Africa (Serpentes: Elapidae). Zootaxa 4455:68-98

Open Access This chapter is licensed under the terms of the Creative Commons Attribution 4.0 International License (http://creativecommons.org/licenses/by/4.0/), which permits use, sharing, adaptation, distribution and reproduction in any medium or format, as long as you give appropriate credit to the original author(s) and the source, provide a link to the Creative Commons licence and indicate if changes were made.

The images or other third party material in this chapter are included in the chapter's Creative Commons licence, unless indicated otherwise in a credit line to the material. If material is not included in the chapter's Creative Commons licence and your intended use is not permitted by statutory regulation or exceeds the permitted use, you will need to obtain permission directly from the copyright holder. 